\title{
FOURTEEN SPECIES OF THE GENUS PARADOXOSTOMA FISCHER, 1855 IN THE INLAND SEA, JAPAN (OSTRACODA)
}

\section{$\operatorname{AUTHOR}(\mathrm{S}):$}

Okubo, Ichiro

\section{CITATION:}

Okubo, Ichiro. FOURTEEN SPECIES OF THE GENUS PARADOXOSTOMA FISCHER, 1855 IN THE INLAND SEA, JAPAN (OSTRACODA). PUBLICATIONS OF THE SETO MARINE BIOLOGICAL LABORATORY 1977, 24(1-3): 99-131

ISSUE DATE:

1977-11-30

URL:

http://hdl.handle.net/2433/175955

RIGHT: 


\title{
FOURTEEN SPEGIES OF THE GENUS PARADOXOSTOMA FISGHER, 1855 IN THE INLAND SEA, JAPAN (OSTRACODA) ${ }^{1,2}$ )
}

\author{
ICHIRO OKUBO \\ Okayama Shujitsu Junior College, Okayama, Japan 703
}

With Text-figures $1-20$ and Table 1

Recently I have collected marine ostracods in intertidal zones of several coasts in the middle Inland Sea and found fourteen species of the genus Paradoxostoma Fischer, 1855, five known and nine new species, which are to be described in this paper.

As the genus Paradoxostoma possesses specialized mouth parts, it may inhabit algae, sucking their sap. In the Inland Sea the present genus is one of the most dominant plant-dwelling ostracods. When phytal environments in the intertidal zones are examined, some species within this genus will be surely discovered. In Japanese literature on living marine ostracods, therefore, paradoxostome species have been comparatively much dealt with, though they have scarcely been recorded as fossil probably owing to the fragility of their valves. Seven (all new) species have been reported by Kajiyama (1913) from Kanagawa Pref., nine (eight new, one new to Japan) by Schornikov (1975) from Wakayama Pref., four (three new) by Hiruta (1975) from Hokkaido, and one, three (valves only) and one (fossil) by Ishizaki (1968, '71, '76) from Kochi, Aomori and Sizuoka Prefs., respectively. The species, inclusive of my species, total to twenty-eight.

Hiruta has divided his four species into two groups. But some species in the Inland Sea seem to belong to neither. The survey of more species may separate this genus into several groups.

I wish to express my thanks to Prof. A. Inaba of Hiroshima University and Prof. T. Hanai of the University of Tokyo for their invaluable advice. My thanks are also due to Mr. M. Isozaki of Okayama University for his help in collecting some species.

\section{Material and Station Data}

Specimens examined herein have been collected in intertidal zones of the following coasts in the middle Inland Sea.

1) Recent Marine Ostracoda in the Inland Sea, Japan-VI

2) Contribution from the Mukaishima Marine Biological Station, No. 147.

Publ. Seto Mar. Biol. Lab., XXIV (1/3), 99-131, 1977.

(Article 12) 
(I) Innoshima Island $\left(133^{\circ} 10.8^{\prime} \mathrm{E}, 34^{\circ} 21.0^{\prime} \mathrm{N}\right), 25-\mathrm{VIII}-1976$.

(MBS) Mukaishima Marine Biological Station $\left(133^{\circ} 13.2^{\prime} \mathrm{E}, 34^{\circ} 21.7^{\prime} \mathrm{N}\right)$, on various days, date supplemented.

(A) Ategi Islet $\left(133^{\circ} 15.6^{\prime} \mathrm{E}, 34^{\circ} 19.7^{\prime} \mathrm{N}\right), 28-\mathrm{VII}-1976$.

(W) Wasajima Island $\left(133^{\circ} 47.4^{\prime} \mathrm{E}, 34^{\circ} 23.4^{\prime} \mathrm{N}\right), 10-\mathrm{VII}-1976$.

(H) Hoden $\left(134^{\circ} 6.6^{\prime} \mathrm{E}, 34^{\circ} 35.1^{\prime} \mathrm{N}\right), 27-\mathrm{VI}-1976$.

(M) Maejima Island $\left(134^{\circ} 10.4^{\prime} \mathrm{E}, 34^{\circ} 36.0^{\prime} \mathrm{N}\right), 7-\mathrm{VIII}-1976$.

(K) Kojima Island $\left(134^{\circ} 15.9^{\prime} \mathrm{E}, 34^{\circ} 41.6^{\prime} \mathrm{N}\right)$, 2-VIII- 1976 .

Capitals in parentheses are symbols of Stations.

I, MBS, A in Hiroshima Pref., W in Kagawa Pref., H,M,K in Okayama Pref.

In the Material column of each species, [MO-provisional No., Sex, Left, Right valve (length-height) in $0.01 \mathrm{~mm}$, Symbol of Station] is to be written. The specimens reported in this paper are dissected and embedded in Canada balsam (valves) and in Neo-Shigaral (soft parts).

\section{Genus Paradoxostoma Fischer, 1855}

\section{Type-species: Cythere variabilis Baird, 1835}

Description. Carapace small, laterally compressed, thin, semi-transparent. Surface usually smooth. Adductor muscle scars four in vertical row, with or without two small additional scars in front of the upper one. Normal pore canals small in number.

Valves oval, reniform or various forms in lateral view; greatest height behind the middle. Anterior end narrower and lower than the posterior. Ventral margin almost straight. Both left and right valves sub-equal to each other in size and shape, but usually left valve with wider fused zone antero-dorsally, and right valve with more prominent caudal process. In a few species valves having sexual dimorphism in size, shape and/or coloration.

Selvage peripheral, well to scarcely developed; when wide, showing complicated shape in cross section. Two or three striae present. Infold rather wide. Inner margin smooth. Fused zone narrow or medium; line of concrescence smooth, or irregular where fused zone wide. Radial pore canals small in number. Hinge lophodont.

Antennula slender, composed of six podomeres. First, second podomere without seta. Second podomere sub-equal in length to third, fourth podomere. Third, fourth podomere rather heavily chitinized. Third podomere with a seta at anterodistal end. Fourth, fifth podomere with two setae at antero-distal end and a seta at postero-distal end. Sixth podomere with three or four setae distally.

Antenna of five podomeres. Fisrt podomere large, without seta. Second podomere with a seta postero-distally. Third podomere with one (or two) seta postero-distally. Fourth podomere with a seta postero-distally; anterior margin often 
subdivided at the middle, the juncture becoming setiferous ledge to bear a hair or a small seta. Fifth podomere small, provided with two claws: strong anterior and fine posterior ones. Spinneret seta (exopodite) three- or four-segmented, the distal joint being knee.

Mandible of characteristic shape. Coxa styliform, with fine seta at lower
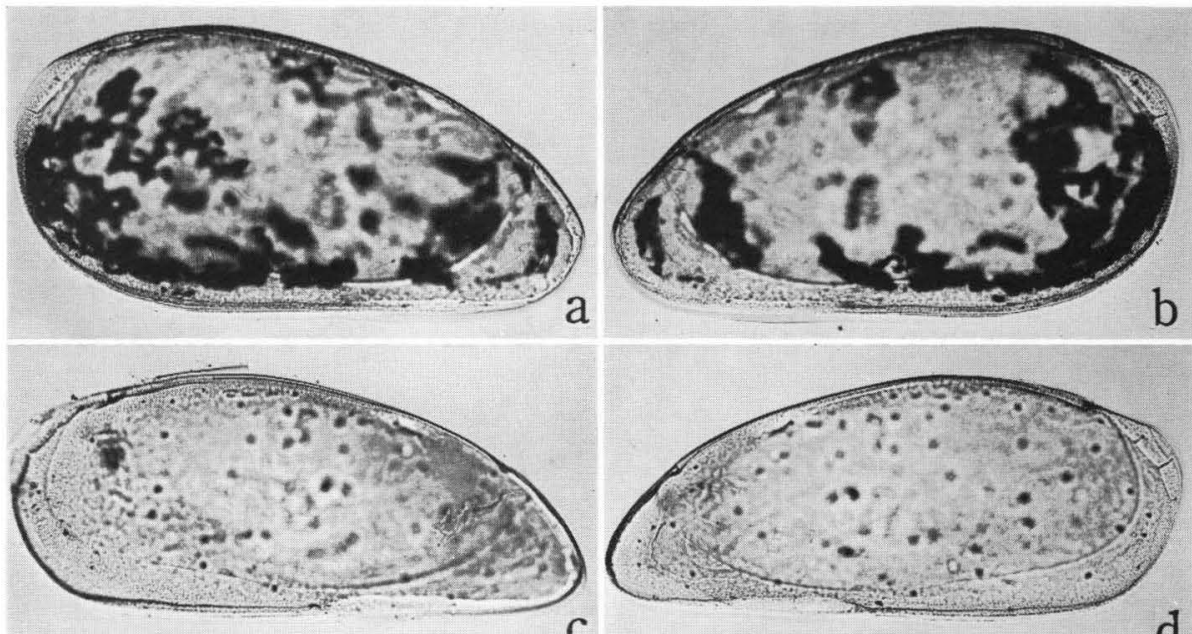

C

$\mathrm{d}$
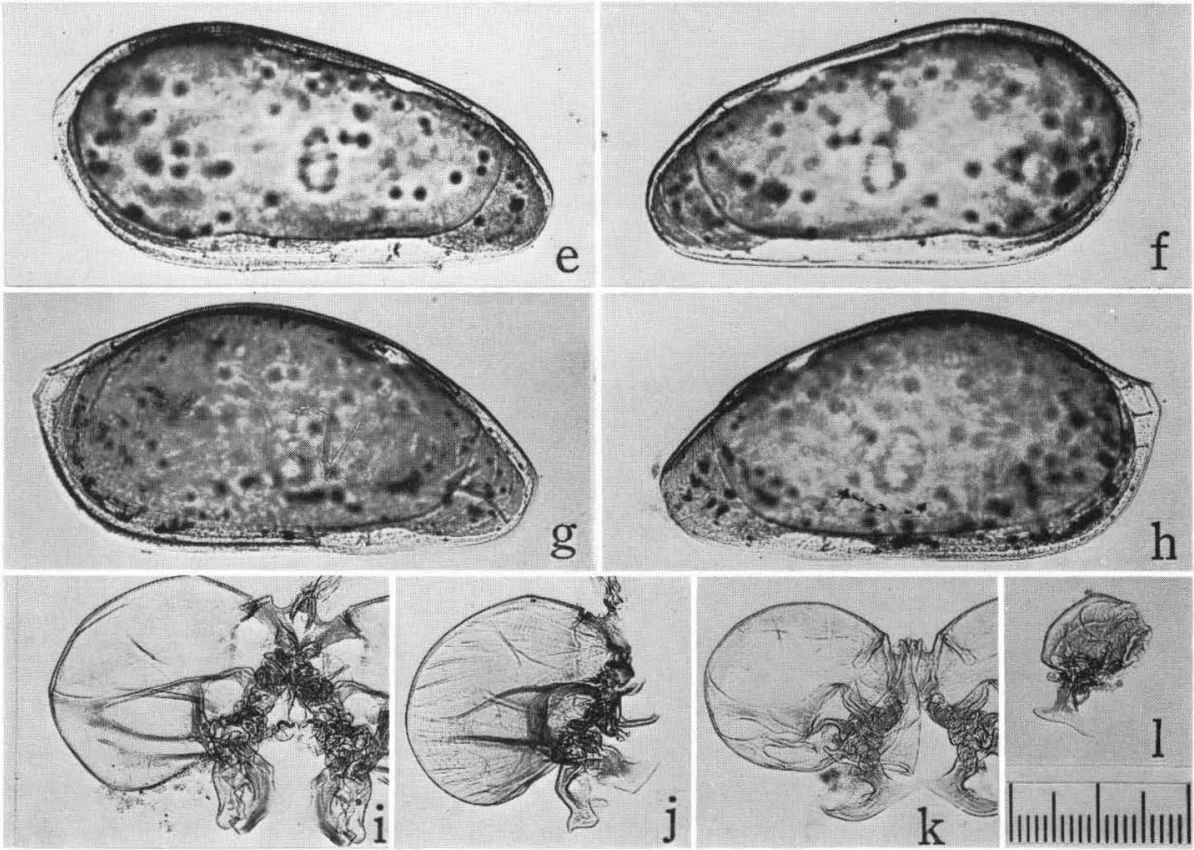

Fig. 1. Paradoxostoma. a, b, i, P. pedale, ô (MO-367). c, d, j, P. coniforme: c, d, \& (MO-369), j, ô (MO-366). e, f, k, P. bingoense, ơ (MO-495). g, h, l, P. yatsui, ô (MO-340). a, c, e, g, left valve; b, d, f, h, right valve; i-l, copulatory organ. Scale given in $0.2 \mathrm{~mm}$ for all. 


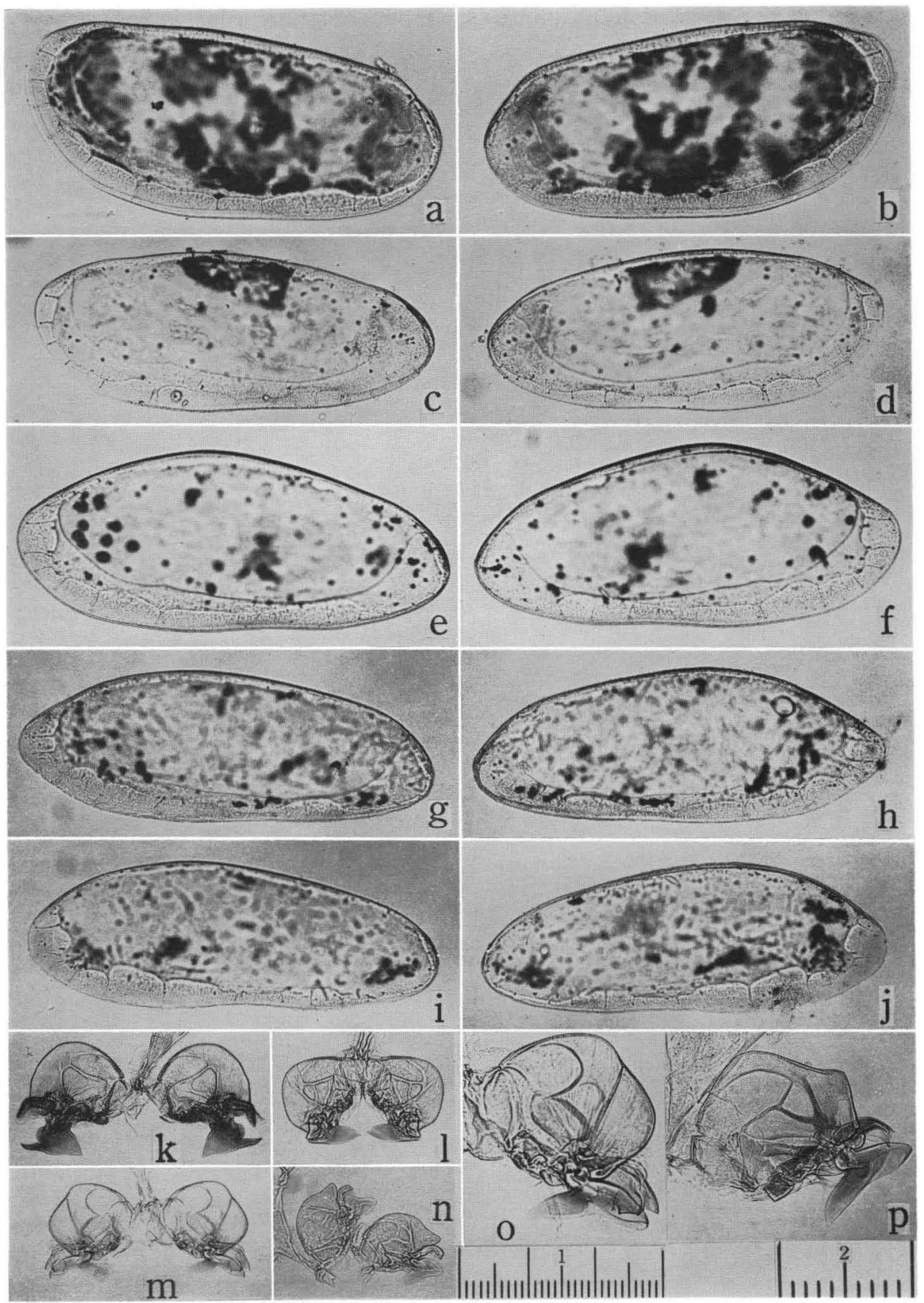

Fig. 2. Paradoxostoma. a, b, k, P. flaccidum: a, b, ô (MO-349), k, ô (MO-435). c, d, 1, P. setoense, ô (MO-402). e, f, m, o, P. convexum: e, f, m, ô (MO-503), o, ô (MO-504). g, h, p, P. affine: g, h, ô (MO-429), p, ô (MO-430). i, j, n, P. depressum, ô (MO-408). $\mathrm{a}, \mathrm{c}, \mathrm{e}, \mathrm{g}$, i, left valve; b, d, f, h, j, right valve; k-p, copulatory organ. Scale: $1(0.3 \mathrm{~mm})$ for a-n; $2(0.1 \mathrm{~mm})$ for $\mathrm{o}, \mathrm{p}$. 
third; lower end, without teeth, terminating in a sharp point; upper part somewhat widened. Palp two- to four-segmented indistinctly, distally with six or seven setae: usually four at distal end, two near the end and one, if present, a little apart from the end. Exopodite, a seta on proximal part of palp, present or absent.

Maxillula: palp atrophied to be a seta or absent. Three masticatory lobes
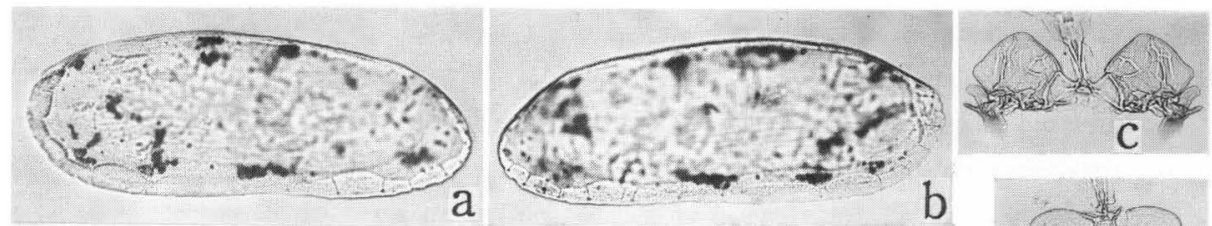

b
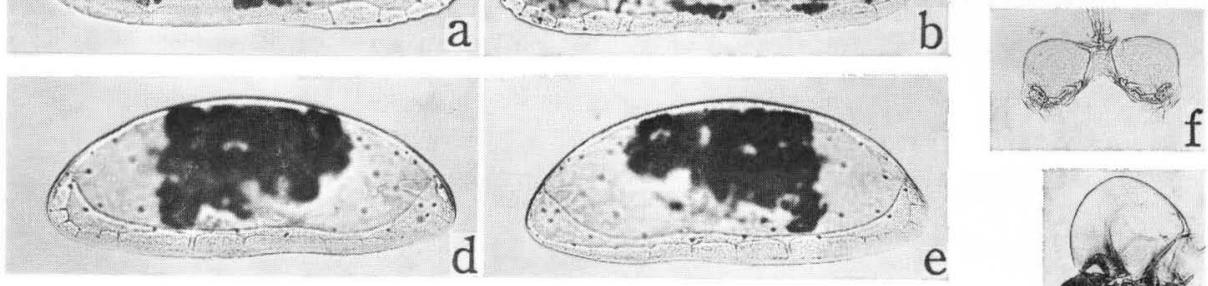

e
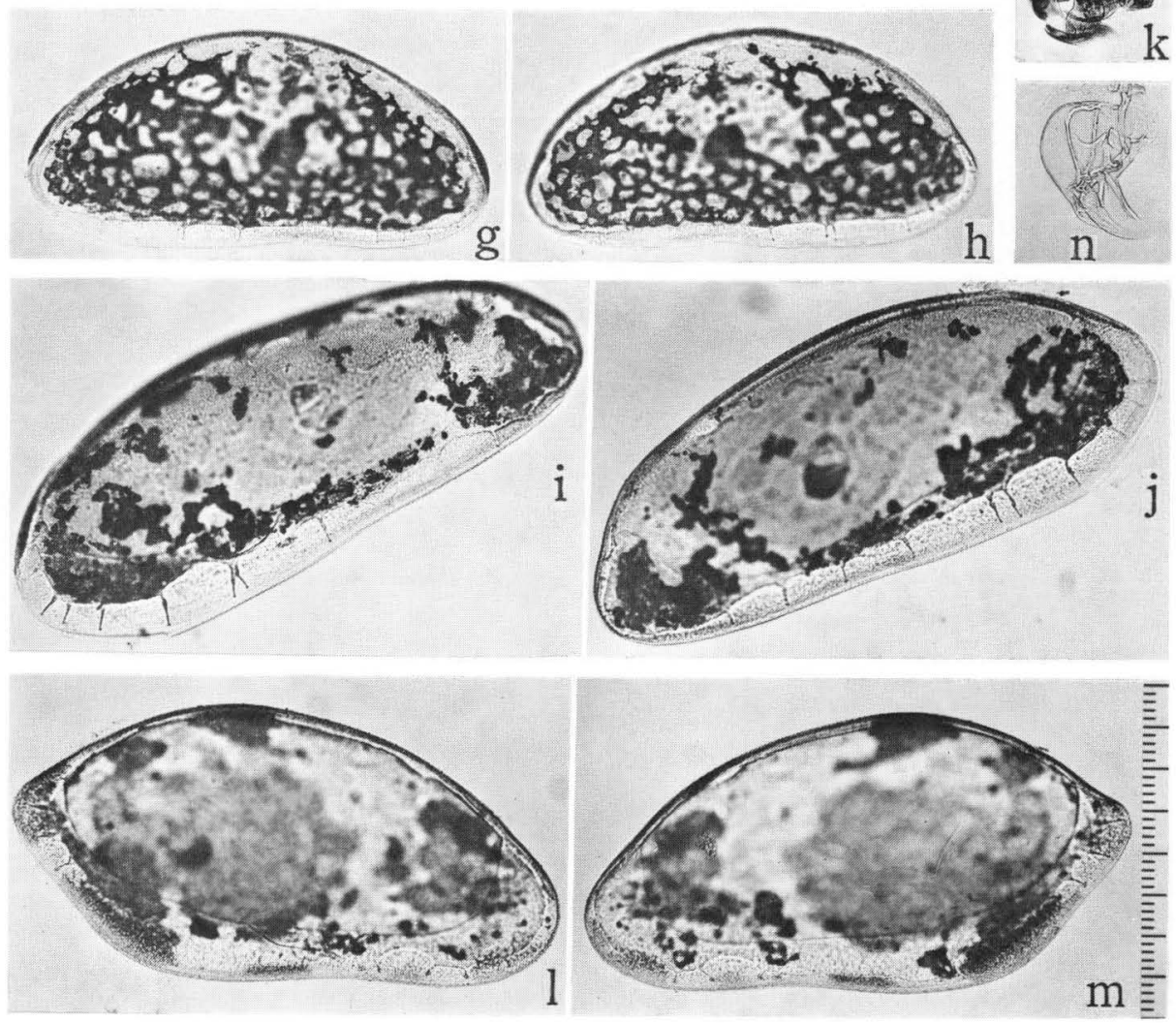

Fig. 3. Paradoxostoma. a-c, P. fragile: a, b, ô (MO-426), c, $\widehat{o}$ (MO-424). d-h, P. lunatum: d-f, ô (MO-415), g, h, 우 (MO-382). i-k, P. denticulatum, ơ (MO-373). 1-n, P. rhomboideum: l, m, ô (MO-412), n, ô (MO-422). a, d, g, i, l, left valve; b, e, h, j, m, right valve; c, f, k, $\mathrm{n}$, copulatory organ.

Scale given in $0.4 \mathrm{~mm}$ for all. 
existing: inner (first) one small, with two setae, middle and outer ones long, sub-equal to each other in length, with five and six setae, respectively. Vibratory plate with two juxtaposed setae of equal length. Branchial plate with about fifteen long, plumose setae. Oral cone with well-developed sucking disk.

Maxilla, thoracopoda 1, 2 (walking legs) pediform, of four podomeres, increasing in length backward. Setal formula of (antero-medial, antero-distal, posterior) areas of protopodites of maxilla, thoracopoda 1 and 2: (1 seta, 1 claw, 0), (1 seta, 1 seta or claw, 0), (0, 1 seta, 0$)$.

Copulatory organ symmetric, composed of large basal part and usually three diverging processes of various forms; the middle one largest.

(The above generic description is mostly based on data obtained from Japanese species.)
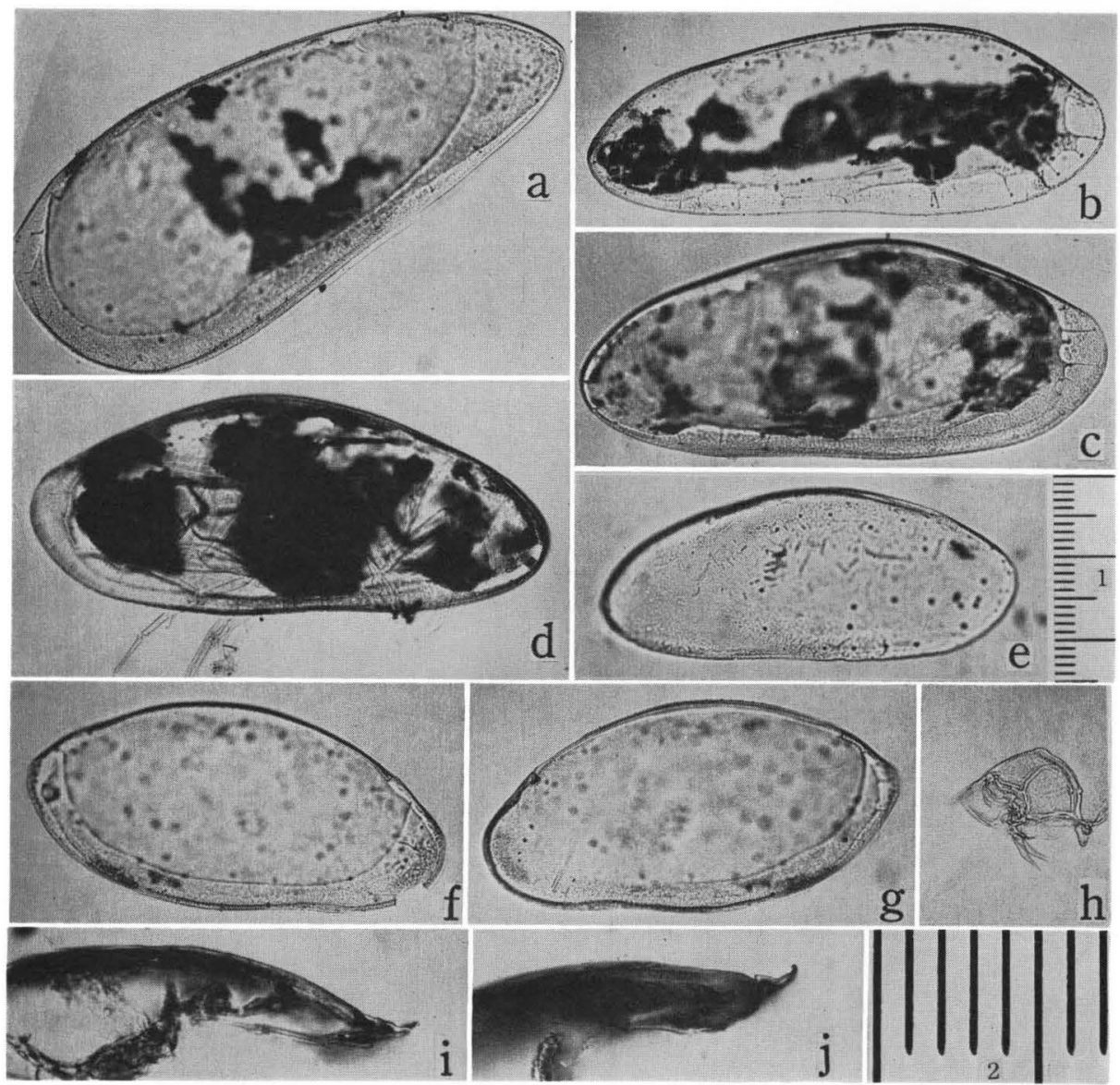

Fig. 4. Paradoxostoma. a, P. coniforme, ô (MO-366), left valve. b, P. depressum, $q$ (MO-403), right valve. c-e, P. convexum: c, \& (MO-358), right valve; d, ㅇ (MO-511), carapace; e, A-1 (MO-506), right valve. f-h, P. setosum, of (MO-423): f, left valve; $g$, right valve; h, copulatory organ. i, j, P. pedale, cross section through ventral margin of left, right valve. Scale: $1(0.25 \mathrm{~mm})$ for a-h, $2(0.07 \mathrm{~mm})$ for $\mathrm{i}, \mathrm{j}$. 
Remarks. Three genera belonging to the Family Paradoxostomatidae Brady \& Norman, 1889, have hitherto been found alive in Japan, viz., Sclerochilus Sars, 1866, Cytherois Müller, 1894, and the present genus. These genera resemble one another

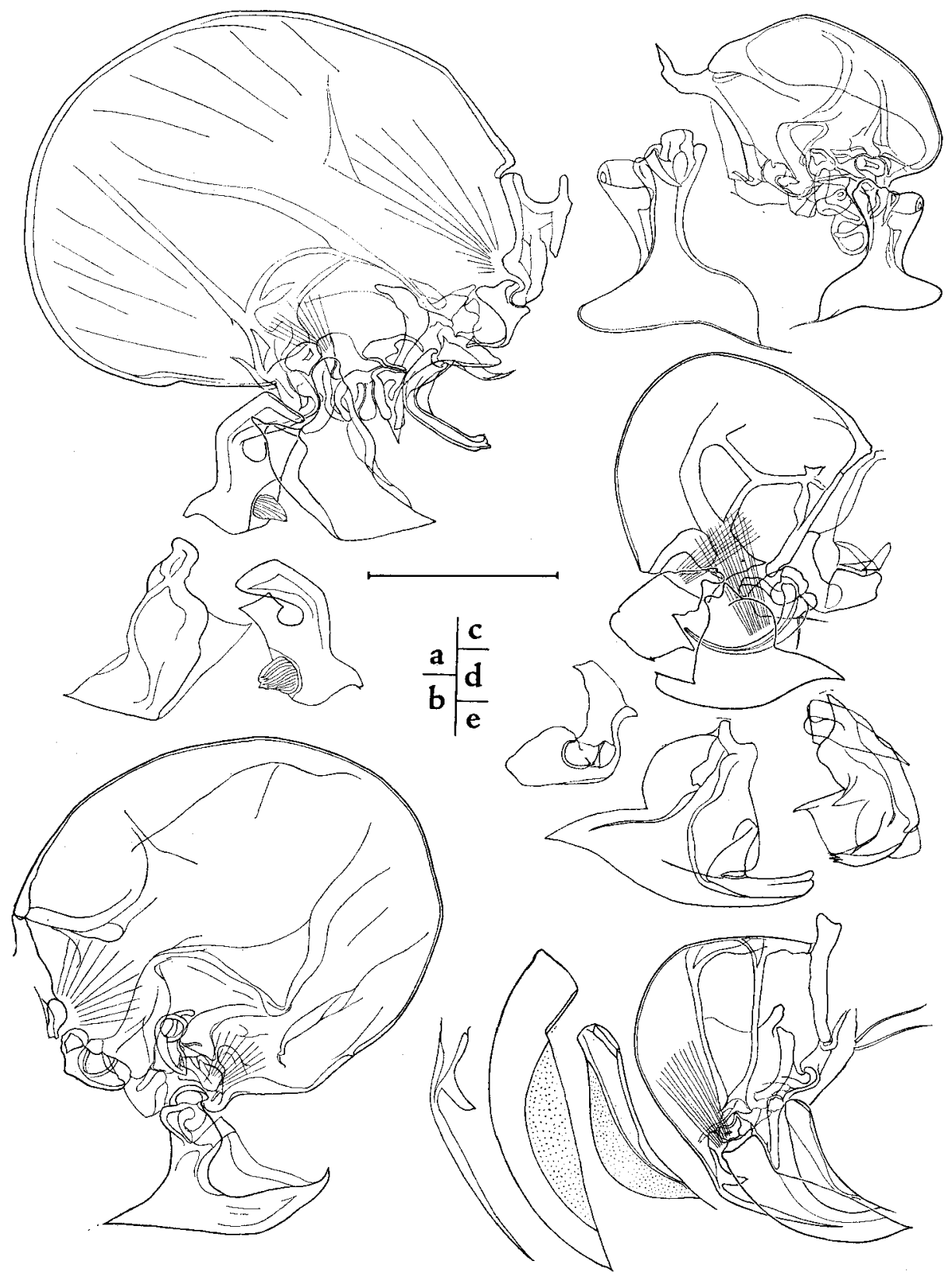

Fig. 5. Copulatory organs. a, Paradoxostoma coniforme (MO-366); b, P. bingoense (MO-495); c, $P$. yatsui (MO-341); d, $P$. denticulatum (MO-373); e, $P$. rhomboideum (MO-422). Scale given in $0.1 \mathrm{~mm}$ for all, except for processes of $\mathrm{c}, \mathrm{d}, \mathrm{e}$. 
in appearance, but Sclerochilus differs from the others in having five adductor muscle sacrs and more radial pore canals, and Cytherois is characteristic in having two large frontal scars in addition to four adductor muscle scars, without mentioning the difference of appendages.

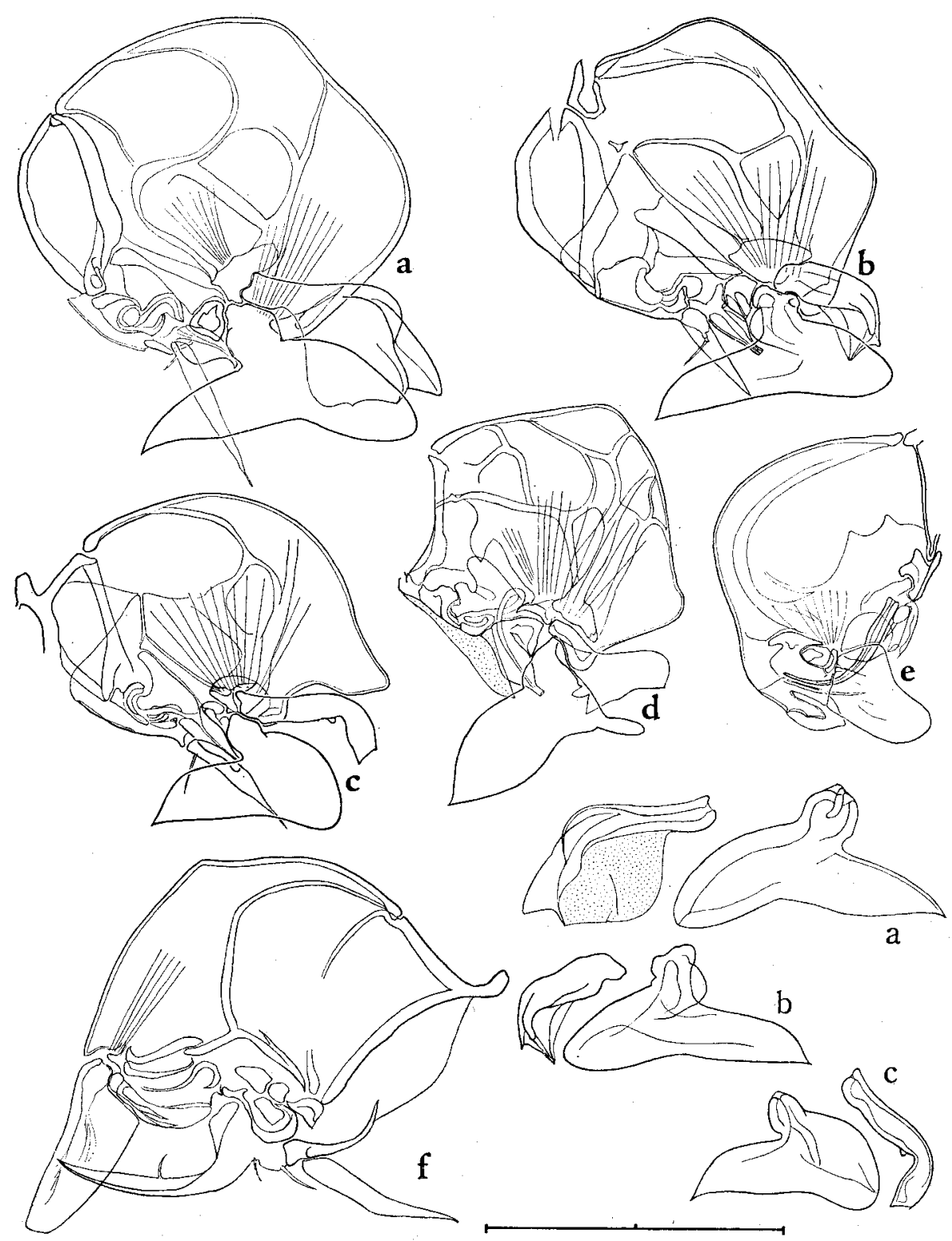

Fig. 6. Copulatory organs. a, Paradoxostoma convexum (MO-504); b, P. affine (MO-430); c, $P$. depressum (MO-408); d, P. fragile (MO-424); e, P. lunatum (MO-415); f, P. setosum (MO423).

Scale given in $0.1 \mathrm{~mm}$. 
Moreover, Paracytherois Müller, 1894, has been discovered by Ishizaki (1968, '69, '71, '76) in states of valves alone or as fossil. This genus differs sharply from Paradoxostoma in the shape of appendages.

Paradoxostoma sp. A (Ishizaki, 1968, p. 36) is thought to be a species of the genus Sclerochilus.

Discrimination among Japanese paradoxostome species is to be discussed in "Key to Japanese Species" and "Affinity of Japanese Paradoxostome Species".

\section{Key to Japanese Species}

A. Fused zone narrow in general, narrower postero-ventrally than antero-ventrally and postero-dorsally.

B. Adductor muscle scars with two additional scars in front of upper one.

C. Caudal process prominent.

P. yatsui (4)

C. Caudal process moderate.

D. Valve rather high; height as large as half length

P. pedale (1)

D. Valve elongate; height less than half length.

$P$. coniforme (2)

C. Caudal process vague.

$P$. bingoense (3)

B. Adductor muscle scars without two additional scars in front of upper one.

P. setosum (14)

A. Fused zone moderate in width, rather wide postero-ventrally.

B. Valve sub-reniform.

C. Valve with spine postero-ventrally.

P. denticulatum (12)

C. Valve without prominent spine postero-ventrally

D. Valve $0.5 \mathrm{~mm}$, ornamented with a number of fine longitudinal striae.

D. Valve $0.6 \mathrm{~mm}$ or more, without fine striae.

P. fragile (10)

E. Fused zone smooth posteriorly.

F. Valve highest posteriorly.

$P$. flaccidum (5)

F. Valve highest behind the middle.

$P$. setoense (6)

E. Fused zone rather irregular posteriorly.

F. Valve angulated at highest point.

P. convexum (7)

F. Valve with evenly arched dorsal margin.

G. Valve with slightly angulated antero-dorsal margin and rather sharpened posterior end.

P. affine (8)

G. Valve with rounded antero-dorsal margin and narrowly rounded posterior margin.

P. depressum (9)

B. Valve lunate.

P. lunatum (11)

B. Valve sub-rhomboid.

P. rhomboideum (13)

(This is for valves; copulatory organs, as shown in Figs. 5,6, will discriminate among the species without difficulty) 


\section{Systematic Description}

\section{Paradoxostoma pedale Hiruta, 1975}

(Figs. 1 a,b,i ; 4 i, j; 7 a-c)

Paradoxostoma pedale, Hiruta, 1975, p. 118, figs. 1-3, pl. IV-1, Japan (Hokkaido).

Material. MO-432, đै, LV(60-30), RV(60-31), MBS, 11-VIII-1976. MO-362, ๙ิ, LV(64-33), RV(65-33), W. MO-379, ㅇ, LV(58-28), RV(57-27), MBS, $11-$ VII-1976. MO-387, ㅇ, LV(56-28), RV(56-28), A.

Occurrence. Rather common, rather abundant.

Remarks. Specimens in the Inland Sea agree well with those in Hokkaido, in the shape of valves and copulatory organs.

Spinules of the thoracopoda 2 are twelve to fifteen in number, more than in Hiruta's. The number varies even between the left and right legs of one and the same individual.
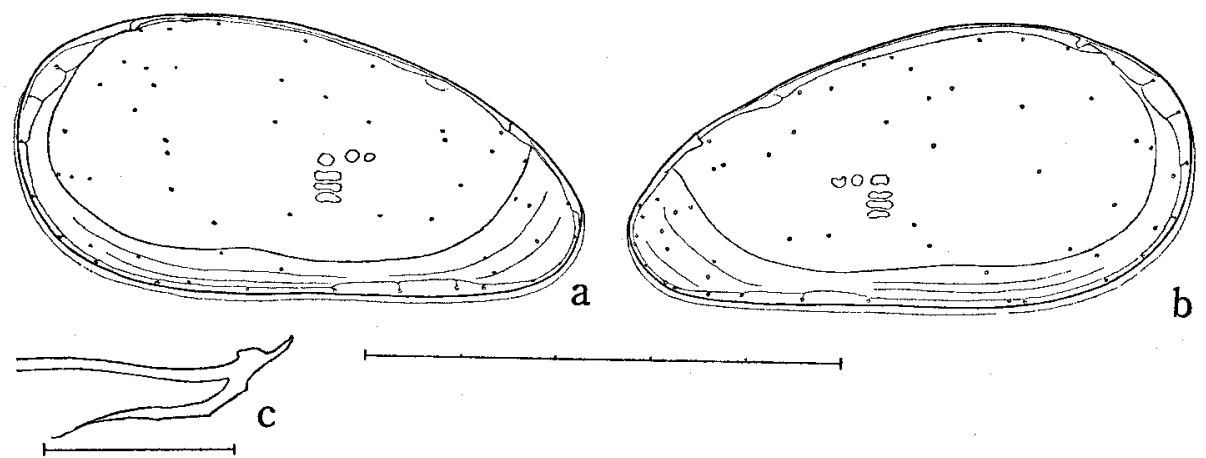

Fig. 7. Paradoxostoma pedale. $\delta(\mathrm{MO}-432)$. a, left valve; b, right valve.

Scale given in $0.5 \mathrm{~mm}$.

c, cross section through postero-ventral margin of left valve decalcified. (Scale given in 0.05 $\mathrm{mm}$ )

Structure of marginal area. Selvage well-developed, peripherally. In cross sections, a swelling existing outside of selvage; proximal end of the swelling, sharpened, may be called flange. On infold, two or three projections present; two proximal ones are striae, the most distal one, when prominent, may be named list.

\section{Paradoxostoma coniforme Kajiyama, 1913}

(Figs. 1 c, d, j; 4 a; 5 a; 8 a-i)

Paradoxostoma coniforme, Kajiyama, 1913, p. 5, pl. 1, figs. 30-33, Japan (Kanagawa Pref.); Ishizaki, 1971, p. 92, pl. 4, fig. 24, Japan (Aomori Pref.).

Description. Carapace drab, without special coloration. Left valve elongate oval in lateral view; greatest height three-sevenths of length, situated at three-fifths of length from anterior end. Dorsal margin gently arched. Anterior margin small, 
distortedly rounded; the extremity at lower fifth. Posterior margin conspicuously warpedly rounded; the extremity at seven-tenths height, where caudal process exists. Ventral margin almost straight, connecting with anterior and posterior margins without any boundaries. Right valve sub-equal in size and shape to the left. Female rather smaller than male.
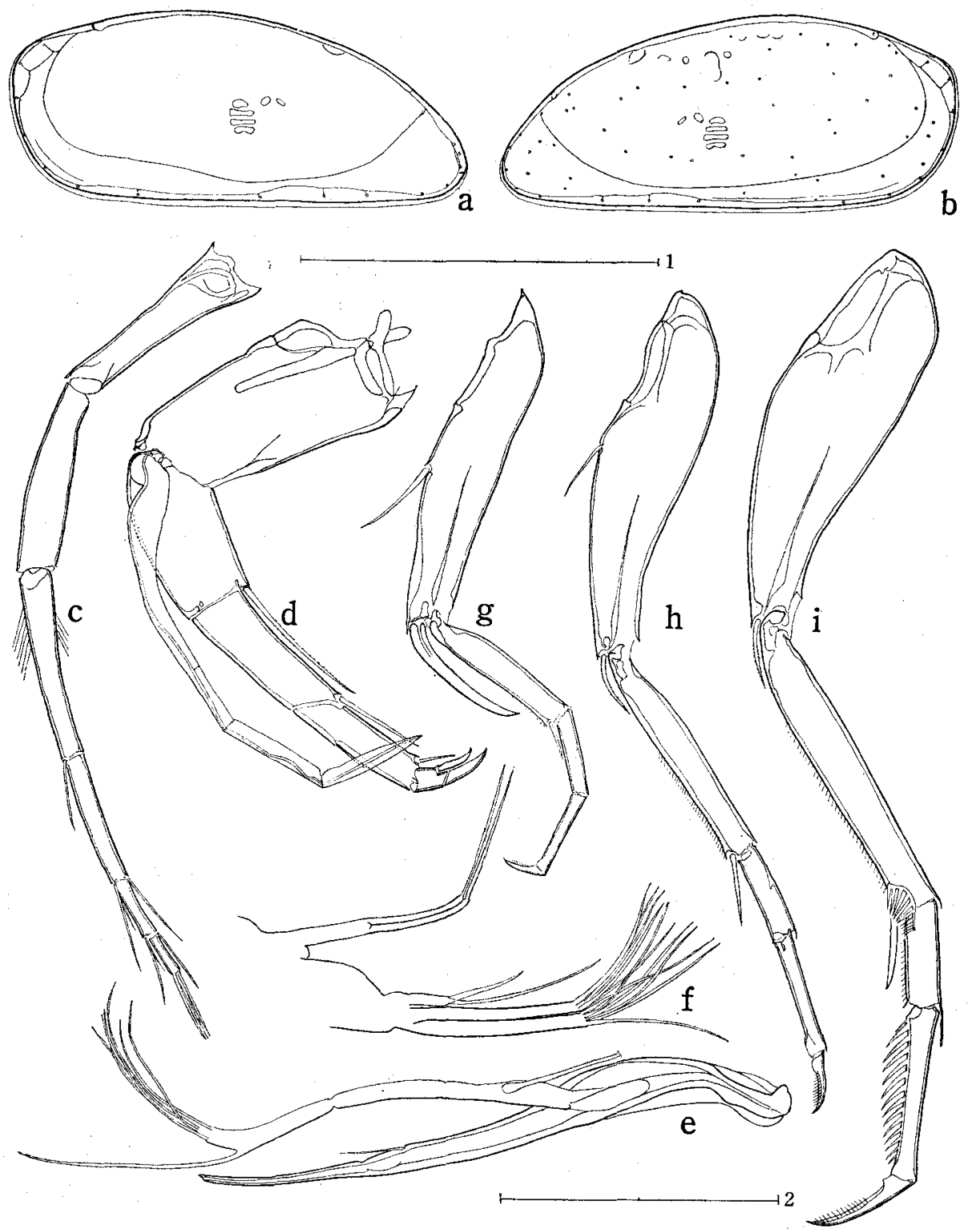

Fig. 8. Paradoxostoma coniforme. 9 (MO-369). a, left valve; b, right valve; c, antennula; d, antenna; e, mandible; $f$, maxillula; $g$, maxilla; $h$, thoracopoda 1 ; $i$, thoracopoda 2. Scale: $1(0.5 \mathrm{~mm})$ for $\mathrm{a}, \mathrm{b} ; 2(0.1 \mathrm{~mm})$ for $\mathrm{c}-\mathrm{i}$. 
Selvage peripheral, well-developed. Infold wide anteriorly, somewhat narrow along antero-ventral margin. Inner margin smooth. Striae very faint. Fused zone narrow as a whole, slightly wide along antero-ventral, and rather wide along postero-dorsal, margin. Radial pore canals about 15 in number, antero-ventrally and postero-dorsally several ones having "inner ducts". Adductor muscle scars with additional two scars in front of upper one.

Antennula: second to sixth podomeres having length ratio of $59: 54: 38: 17: 12$, along anterior margins toward distal end. Antenna: second to fifth podomeres having length ratio of roughly $6: 5: 2+3: 1$, along anterior margins; spinneret seta three-segmented at ratio $8: 3: 3$.

Mandible: exopodite present; palp three-segmented, with seven distal setae, one of which is a little apart from the others. Maxillula without palp.

Walking legs: second to fourth podomeres of maxilla and thoracopoda 1 and 2 having length ratio of $(16: 9: 10):(24: 10: 13):(32: 12: 18)$, along posterior margins. Thoracopoda 1: protopodite with distal seta, not claw. Thoracopoda 2: second podomere with several spinules surrounding distal seta; fourth podomere with a dozen of spinules along anterior margin.

Copulatory organ conspicuously large; basal part elliptical, anterior and middle processes quadrangular.

(Other characters, cf. generic description)

Material. MO-366, of, LV(71-30), RV(71-?), W. MO-369, ㅇ, LV(65-28), RV (65-28), W.

Occurrence. Rare.

Remarks. Specimens in the Inland Sea agree well with Kajiyama's in the shape of valves and copulatory organs.

\section{Paradoxostoma bingoense sp. nov.}

(Figs. 1 e, f, k; 5 b; 9 a-i)

Description. Coloration drab, not easily vanishing after death. Left valve oval in lateral view; greatest height half of length, at three-fourths of length from anterior margin. Dorsal margin somewhat rounded, inclining forward. Anterior margin narrowly rounded, facing the antero-ventral; the extremity at lower fourth. Posterior margin broad, the extremity at three-fifths of height. Ventral margin almost straight. Right valve sub-equal to the left in size and outline.

Selvage well-developed. Infold wide anteriorly, narrow ventrally and posteriorly. Two striae prominent. Fused zone almost absent anteriorly, rather wide antero-ventrally, narrow mid-ventrally to posteriorly. Radial pore canals about 18 in number; anterior ones without "inner ducts", ventral and posterior ones with very short "inner ducts"; two postero-ventral ones approaching to each other. Adductor muscle scars rather large, with two anterior scars. Hinge rather wide.

Antennula: distal five podomeres having length ratio of $5: 4: 5: 2: 1$, along anterior 
margins. Antenna: distal three podomeres having length ratio of $34: 39: 9$, along anterior margins; spinneret seta rather thick, three-segmented at length ratio of $8: 3: 3$, terminal segment slightly longer than the penultimate; proximal segment with signs of segmentation.
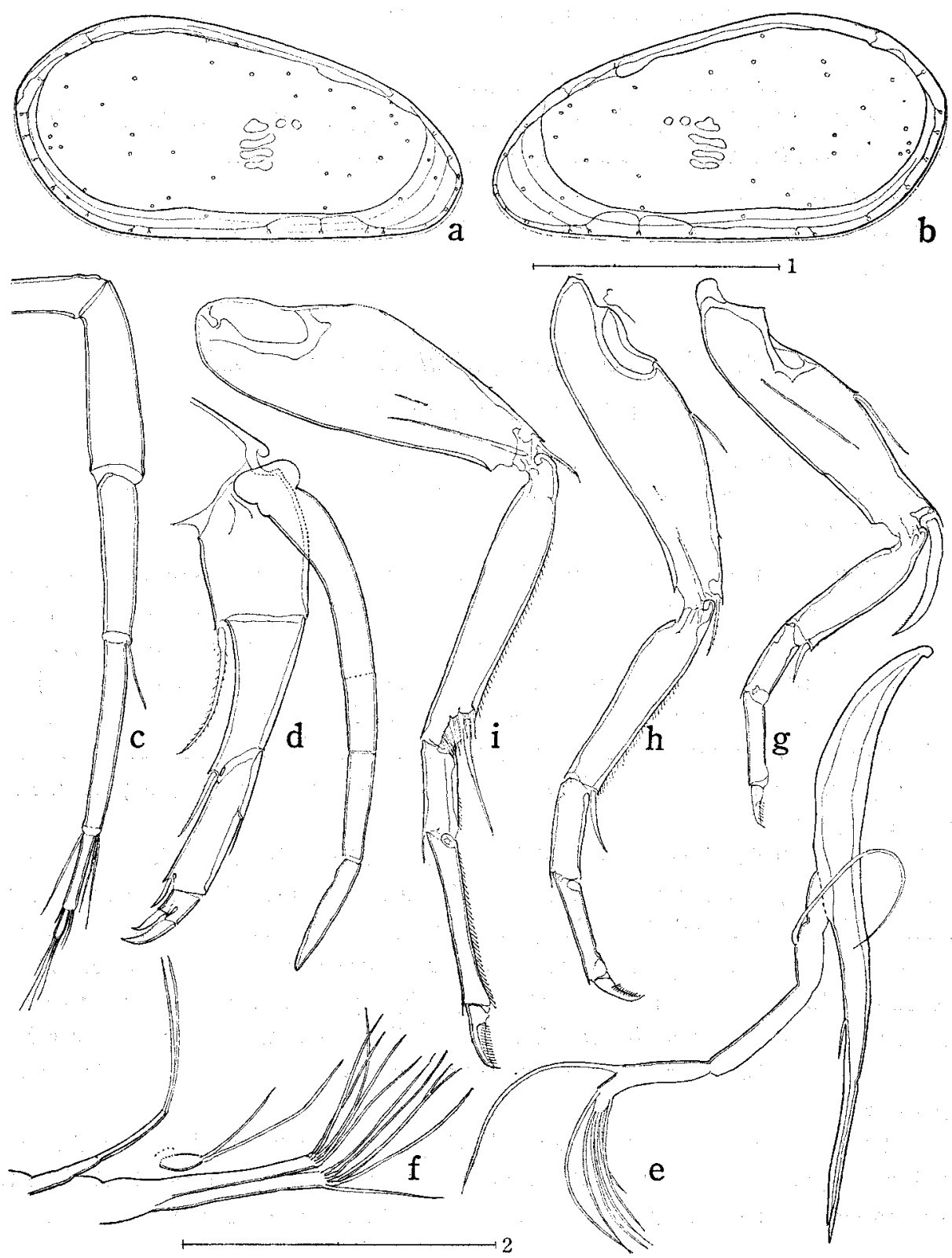

Fig. 9. Paradoxostoma bingoense. ot (MO-495). a, left valve; b, right valve; $c$, antennula; $d$, antenna; e, mandible; f, maxillula; g, maxilla; $h$, thoracopoda 1; i, thoracopoda 2 . Scale: $1(0.3 \mathrm{~mm})$ for $\mathrm{a}, \mathrm{b} ; 2(0.1 \mathrm{~mm})$ for $\mathrm{c}-\mathrm{i}$. 
Mandible: exopodite present; palp with seven setae. Maxillula: palp absent.

Walking legs: second to fourth podomeres of maxilla and thoracopoda 1 \& 2 having length ratio of $(32: 19: 21):(48: 24: 29):(69: 24: 46)$. Thoracopoda 1: protopodite with distal seta, not claw. Thoracopoda 2: second podomere with a bundle of spinules round antero-distal seta. Terminal claws with hairs along distal half.

Copulatory organ relatively large; basal part circular; process v-shaped, anterior and posterior ends pointed.

(Other characters: cf. generic description)

Material. MO-386, ơ (holotype), LV(54-27), RV(54-28), A. MO-495, oै, LV(57-28), RV(56-29), I. MO-496, ?, LV(56-28), RV(56-28), I.

Occurrence. Rare.

Remarks. This new species is characteristic in the copulatory organ with a $\mathrm{v}$-shaped process.

\section{Paradoxostoma yatsui Kajiyama 1913}

(Figs. $1 \mathrm{~g}, \mathrm{~h}, 1 ; 5 \mathrm{c} ; 10 \mathrm{a}-\mathrm{i}$ )

Paradoxostoma Yatsui, Kajiyama, 1913, p. 7, pl. 1, figs. 43-49, Japan (Kanagawa Pref.). P. yatsui, Ishizaki, 1968, p. 36, pl. 9, figs. 5, 6, Japan (Kochi Pref.); Hanai, 1959, p. 435;- 1965 , p. 456 , fig. 424 .

Description. Colour light drab, without special pattern; the colour hardly vanishing after death. Left valve oval in lateral view; greatest height half of length, at three-fifths of length from anterior end. Dorsal margin rather evenly arched, connecting with the anterior at faint angle, with the posterior at conspicuously projected caudal process. Anterior margin rounded small. Posterior margin almost straight or slightly concave along its middle part, largely rounded along its lower part. Ventral margin almost straight. Right valve equal in outline to, very slightly shorter and higher than, the left.

Selvage well-developed, some $0.01 \mathrm{~mm}$ in width. Infold rather wide along anterior margin, narrow along the posterior and ventral. Inner margin rather smooth. Two striae existing along free margins. Fused zone narrow, except along antero-ventral and postero-dorsal margins where it is somewhat wide. Radial pore canals 15 in number: seven anteriorly, eight posteriorly; three antero-ventral and four postero-dorsal ones having "inner ducts"; the rest without them, resembling normal pore canals. Adductor muscle scars with two additional scars in front of upper one.

Antennula: distal five podomeres having length ratio of $11: 8: 10: 4: 2$, along anterior margins. Antenna: distal four podomeres having length ratio $22: 18: 9+12: 5$, along anterior margins; spinneret seta rather thick, three-segmented at ratio of $31: 9: 11$.

Mandible: exopodite existing; palp with seven setae. Maxillula without palp. Walking legs: length ratio of second to fourth podomeres and (claw) of walking 

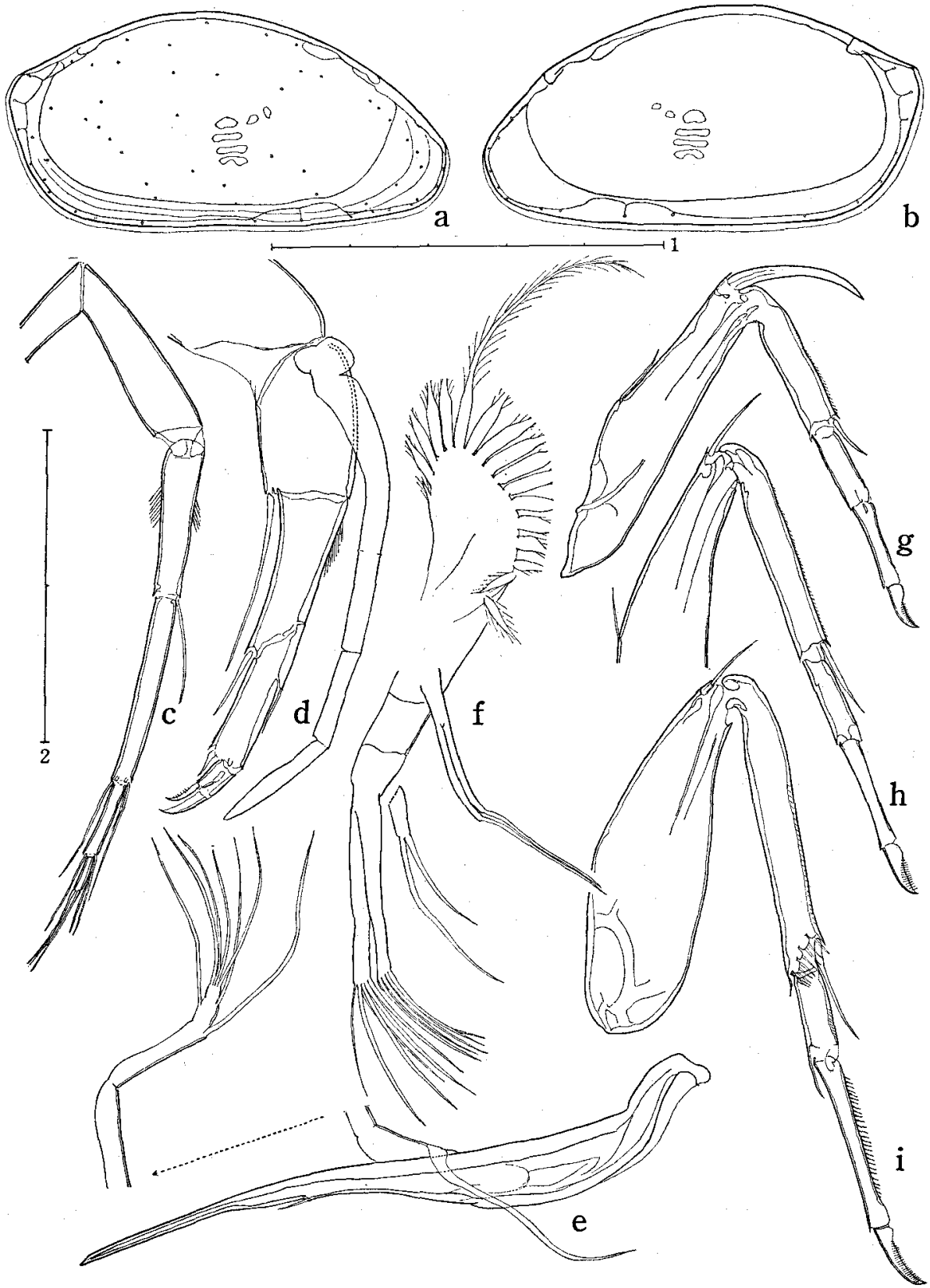

Fig. 10. Paradoxostoma yatsui. a-e, g-i, ô (MO-340); f, के (MO-341). a, left valve; b, right valve (striae, normal pore canals omitted); c, antennula; d, antenna; e, mandible; $f$, maxillula; $\mathrm{g}$, maxilla; $\mathrm{h}$, thoracopoda $1 ; \mathrm{i}$, thoracopoda 2 .

Scale: $1(0.5 \mathrm{~mm})$ for $\mathrm{a}, \mathrm{b} ; 2(0.1 \mathrm{~mm})$ for $\mathrm{c}-\mathrm{i}$. 
legs $[36: 26: 26:(15)]:[52: 26: 35:(16)]:[77: 24: 53:(21)]$. Thoracopoda 1: protopodite with seta distally. Thoracopoda 2 : second podomere distally with ring of spinules surrounding antero-distal seta.

Copulatory organ comparatively small; basal part sub-oval; anterior and middle processes probably fused to be t-shaped one with spine posteriorly.

(Other characters: $\mathrm{cf}$. generic description)

Material. MO-340, ơ, LV(58-29), RV(57-30), H. MO-341, đ, LV(60-30), RV(60-31), H. MO-338, ㅇ, LV(58-30), RV(57-30), H. MO-370, ㅇ, LV(56-28), RV(55-29), W.

Occurrence. Rather common, rather abundant in the Inland Sea.

Remarks. Specimens in the Inland Sea agree well with Kajiyama's in the shape of valves and copulatory organs.

\section{Paradoxostoma flaccidum Schornikov, 1975}

(Fig. $2 a, b, k$ )

Paradoxostoma faccidim (sic), Schornikov, 1975 (Jui.), p. 25, fig. 13, Japan (Wakayama Pref.).

P. ezoense, Hiruta, 1975 (Oct.), p. 133, figs. 9-12, pl. IV-4, Japan (Hokkaido).

Material. MO-349, ðૈ, LV(61-29), RV(61-30), W. MO-435, §ે, LV(61-29), $\mathrm{RV}(60-31)$, W. MO-374, ๙, LV(63-30), RV(62-30), W. MO-350, ㅇ, LV(65-31), RV(64-31), W. MO-348, 이 LV(65-31), RV(63-32), W. MO-376, \&, LV(64-31), RV(64-31), MBS, 11-VII-1976.

Occurrence. One of the most abundant species in intertidal zones of the Inland Sea.

Remarks. Specimens in the Inland Sea agree with those of Schornikov and Hiruta, in the shape of valves and copulatory organs. As for the coloration, most specimens show the same pattern as Hiruta's, but in a few, an anterior black patch becomes very faint to be faded, like Schornikov's.

\section{Paradoxostoma setoense Schornikov, 1975}

(Figs. 2 c, d, 1; $11 \mathrm{a}-\mathrm{d}$ )

Paradoxostoma setoensis (sic), Schornikov, 1975, p. 27, fig. 14, Japan (Wakayama Pref.).

Description. (Supplement) Coloration of great sexual dimorphism; female valves covered with dark bluish pigment on the whole inside; male only on mid-dorsal inside.

Valves postero-ventrally with small step, in front of which selvage is hardly developed, behind which it is moderately developed.

Two radial pore canals juxtaposed postero-ventrally.

Material. MO-353, ô, LV(60-24), RV(60-25), W. MO-402, oै, LV(59-24),

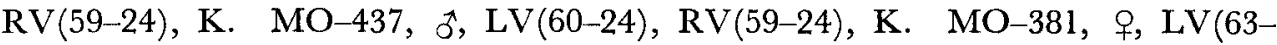



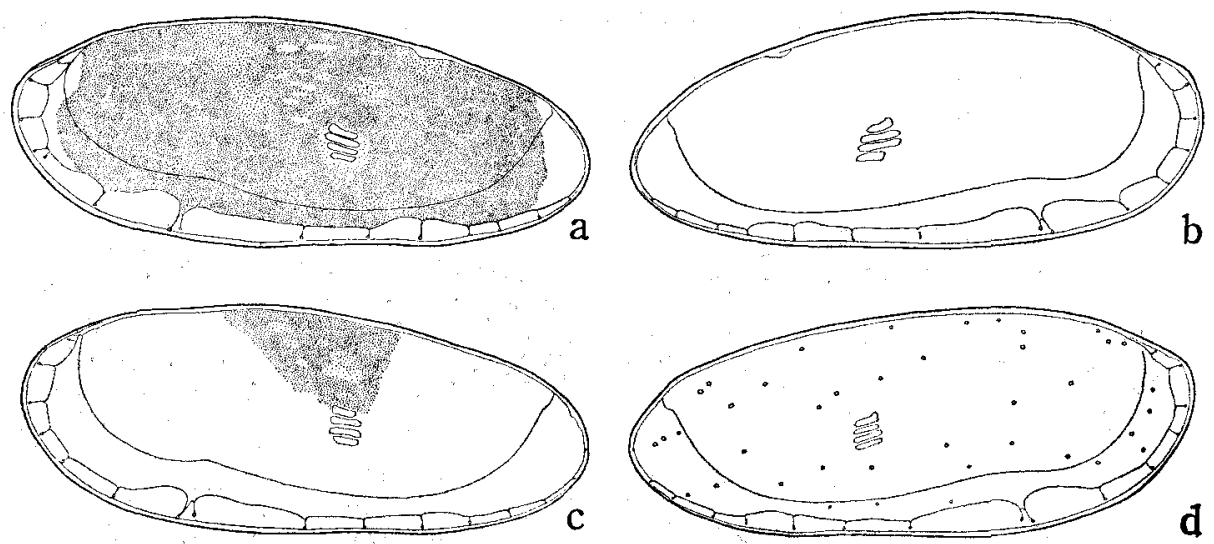

Fig. 11. Paradoxostoma setoense. a, b, $9(\mathrm{MO}-401) ; \mathrm{c}, \mathrm{d}, \delta(\mathrm{MO}-402)$. a, c, left valve; b, d, right valve.

Scale given in $0.5 \mathrm{~mm}$.

25), RV(61-25), MBS, 11-VII-1976. MO-389, 우, LV(59-24), RV(59-24), K. MO-401, ㅇ, LV(59-24), RV(59-24), K.

Occurrence. Gommon and abundant in the Inland Sea.

Remarks. Specimens in the Inland Sea agree well with those from the vicinity of the Seto Marine Biological Laboratory in the shape of valves and copulatory organs, but slightly shorter than the latter.

\section{Paradoxostoma convexum sp. nov.}

(Figs. 2 e, f, m, o; 4 c-e; 6 a ; 12 a-i)

Description. Coloration: anterior, middle and posterior parts of valves covered with blackish pigment, showing distinctive pattern like $P$. flaccidum, in both male and female.

Left valve rather elongate; greatest height just behind the middle, at 55/100 of the length from anterior end. Dorsal margin convex, with clear rounded top; anterior and posterior halves gently descending rather symmetrically, postero-dorsally with slight concave in female, straight or slightly convex in male. Anterior margin with rounded angle at extremity. Posterior margin obliquely rounded; the extremity higher than at the anterior. Ventral margin slightly sinuated in front of the middle. Right valve slightly shorter and higher than the left, postero-dorsal concave more remarkable in female.

Selvage peripheral, hardly developed. Infold rather wide. Inner margin rather smooth, slightly sinuated postero-ventrally. Two weak striae present. Fused zone absent anteriorly, wide antero-ventrally, somewhat narrow mid-ventrally, wide, with slight narrow interval, posteriorly. Line of concrescence greatly irregular. Radial pore canals about 15 in number, ventral to posterior ones with unbranched 
"inner ducts" of various length, anterior ones without them; seventh and eighth (or sixth and seventh) ones from posterior end juxtaposed at postero-ventral margin. In addition, two or three false radial pore canals present along posterior margin.

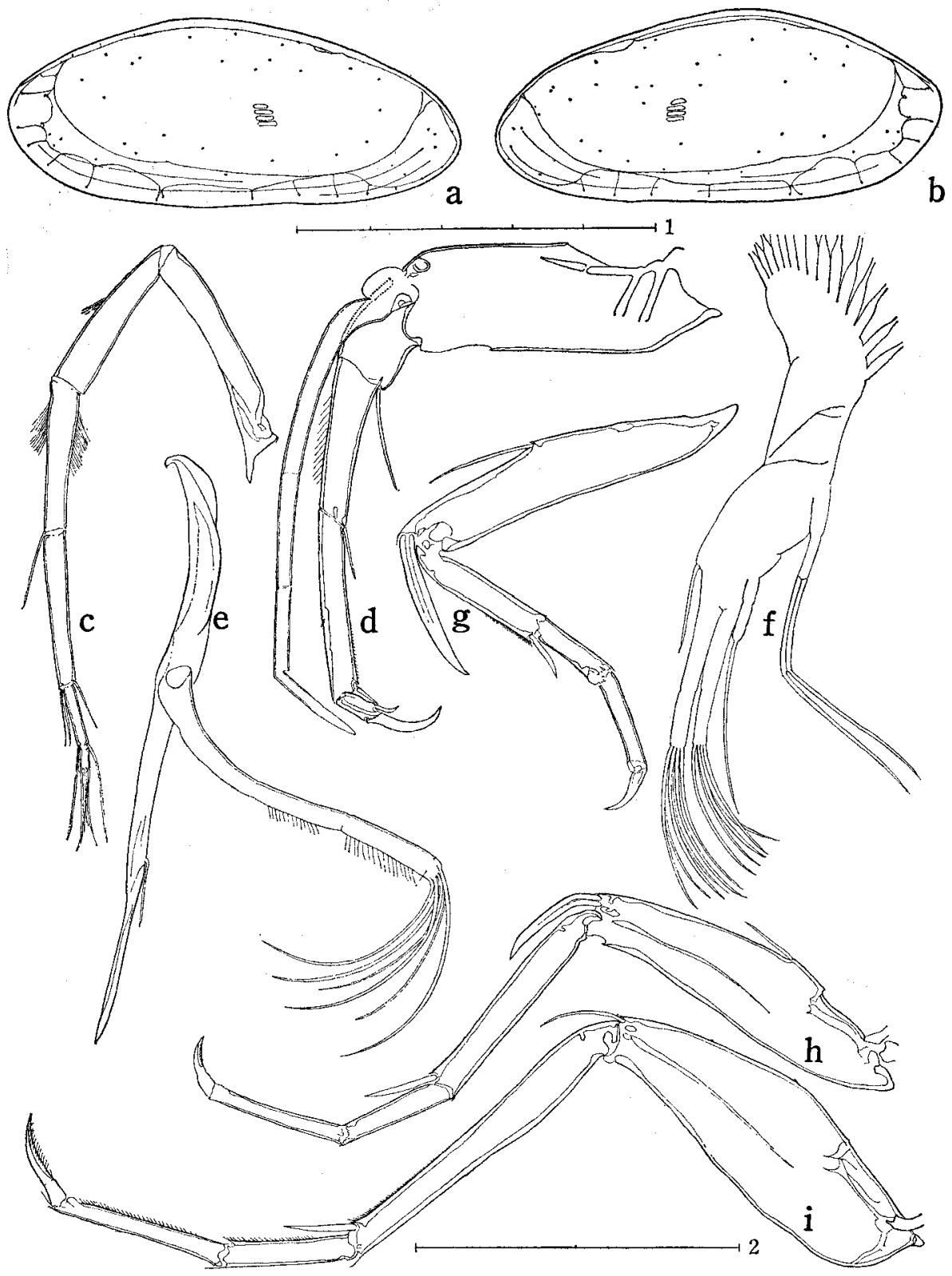

Fig. 12. Paradoxostoma convexum. a, b, e, $\widehat{\sigma}(\mathrm{MO}-504)$; c, d, f-i, $\widehat{\sigma}$ (MO-503). a, left valve; b, right valve; $c$, antennula; $d$, antenna; e, mandible; $f$, maxillula; $g$, maxilla; $h$, thoracopoda 1 ; i, thoracopoda 2 .

Scale: $1(0.5 \mathrm{~mm})$ for $\mathrm{a}, \mathrm{b} ; 2(0.1 \mathrm{~mm})$ for $\mathrm{c}-\mathrm{i}$. 
Normal pore canals small in number, scattered laterally. Adductor muscle scars without additional scars.

Antennula: distal five podomeres having length ratio of 22:18:19:7:3, along anterior margins. Antenna: distal four podomeres having length ratio of $5: 8: 6+4: 2$; terminal claws prominently unequal in size, posterior one degenerated to be small seta; spinneret seta three-segmented in length ratio of roughly $3: 1: 1$; first segment with very fine signs of segmentation at distal two-fifths.

Mandible: palp two-segmented, first podomere with two signs of segmentation; second podomere with six setae distally; no exopodite. Maxillula: palp present; inner masticatory process with short and long setae, middle one with five thick setae, outer one with one thin and five thick setae.

Walking legs: distal three podomeres of maxilla, thoracopoda 1 \& 2 having length ratio of $(12: 9: 10):(22: 12: 14):(32: 14: 16)$, along chitinized posterior margins.

Copulatory organ: basal part rounded sub-square; anterior process of narrow curving chitin rod with thin square lamella; middle process of large, obtuse triangular lamella with rounded anterior end and tapering posterior half; posterior process of narrow rod-shaped lamella.

(Other characters: $\mathrm{cf}$. generic description)

Material. MO-504, o (holotype), LV(64-26), RV(63-28). MO-503, ๙ै, LV (61-25), RV(61-26). MO-505, 우, LV(62-26), RV(61-26). MO-510, 우, LV(6427), $\mathrm{RV}(63-27)$. MO-506, A-1, LV(52-20), RV(51-21). MO-511, 우. All collected at MBS, on 27-X-1976.

Occurrence. Rather common, rather abundant.

Remarks. This new species resembles $P$. oshoroense Hiruta, 1975, and $P$. japonicum Schornikov, 1975, in the shape of valves, but differs from them in the detailed structure of valves and copulatory organs.

\section{Paradoxostoma affine sp. nov.}

(Figs. 2 g, h, p; 6 b; 13 a-i)

Description. Left valve elongate reniform; greatest height three-eighths of length, at three-fifths from anterior end. Dorsal margin arched. Anterior margin rounded narrowly and distortedly, the extremity at lower third. Posterior margin somewhat sharpened; upper and lower halves almost straight; the extremity at half height. Ventral margin almost straight. Right valve sub-equal to the left in size and shape.

Marginal area similar to those of $P$. convexum and $P$. depressum (in this paper); the pattern of fused zone slightly different from theirs.

Antennula: distal five podomeres having length ratio of $21: 18: 19: 6: 3$. Antenna: length ratio of distal four podomeres $11: 17: 11+11: 4$; subterminal claw converted to fine seta; spinneret seta three-segmented with ratio of $28: 7: 9$.

Mandible: exopodite absent; palp with six setae. Maxillula: palp present.

Walking legs: distal three podomeres of maxilla and thoracopoda 1 \& 2 giving 
length ratio of $(26: 19: 24):(43: 26: 28):(66: 29: 40)$, along chitinized posterior margins; terminal claws adorned with hairs distally.

Copulatory organ: basal part, resembling that of $P$. convexum, square, slightly more angulated; processes also similar to those of $P$. convexum.
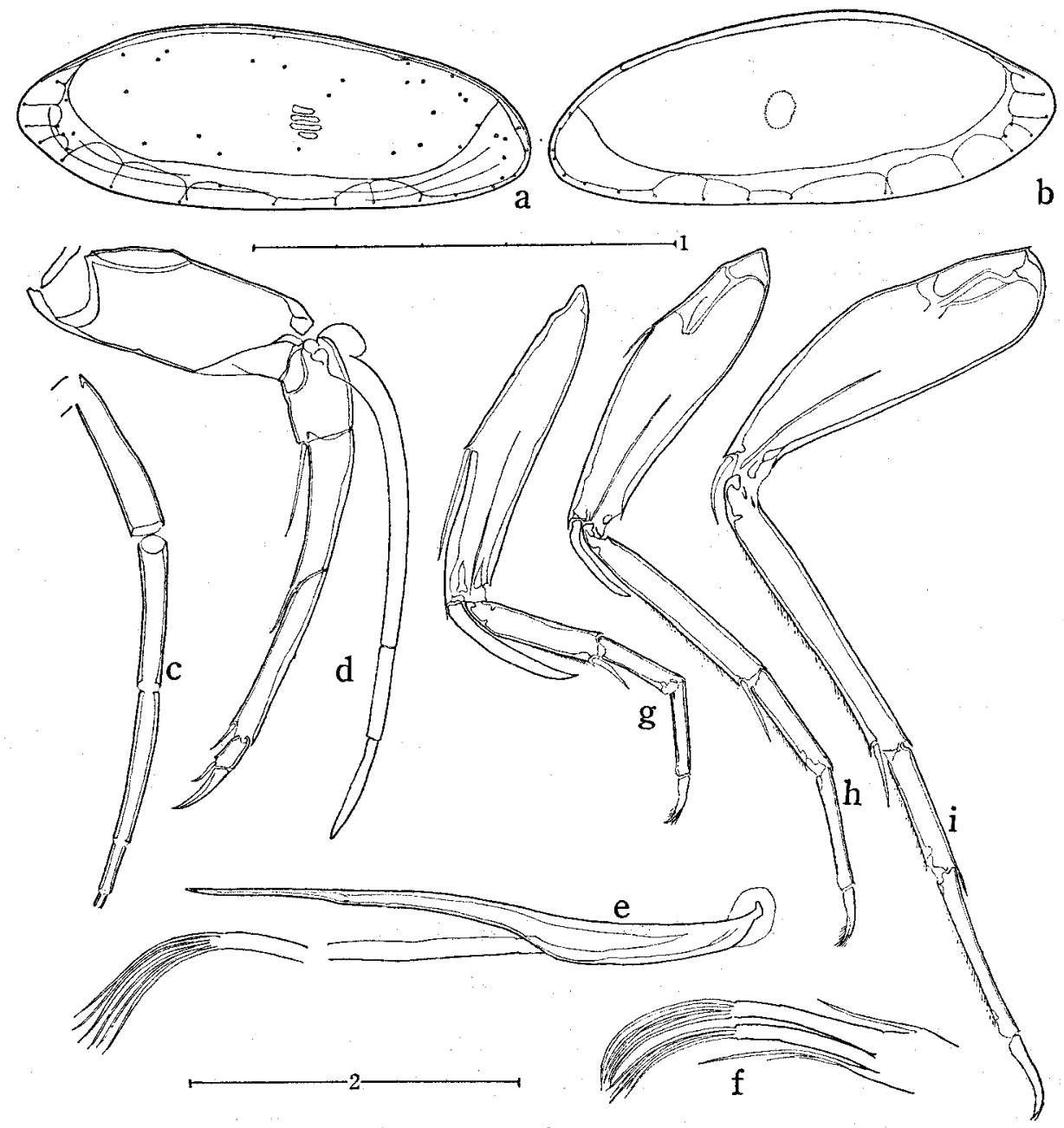

Fig. 13. Paradoxostoma affine. a, b, d, e, ô (MO-429); c, ô (MO-428); f-i, $\tilde{\sigma}$ (MO-430). a, left valve; $b$, right valve; $c$, antennula; $d$, antenna; e, mandible; $f$, maxillula; $g$, maxilla; h, thoracopoda 1 ; i, thoracopoda 2.

Scale: $1(0.5 \mathrm{~mm})$ for a-b; $2(0.1 \mathrm{~mm})$ for $\mathrm{c}-\mathrm{i}$.

(Other characters: $\mathrm{cf}$. generic description)

Material. MO-429, ô (holotype), LV(62-23), RV(61-23), M. MO-428, $\hat{\sigma}$, LV(61-?), RV(61-28), M. MO-430, §, LV(64-24), RV(63-23), M. MO-431, ㅇ, $\mathrm{LV}(62-28), \mathrm{RV}(62-27)$, $\mathrm{M}$.

Occurrence. At Maejima Island, where it is rare. 
Remarks. The new species resembles $P$. convexum in the shape of copulatory organs, but the former has a more angular basal part and a smaller anterior process. The present species also resembles $P$. depressum (in this paper) and $P$. oshoroense Hiruta in the outline of valves, but the former's posterior margins are more pointed.

\section{Paradoxostoma depressum sp. nov.}

(Figs. $2 \mathrm{i}, \mathrm{j}, \mathrm{n} ; 4 \mathrm{~b} ; 14 \mathrm{a}-\mathrm{i}$ )
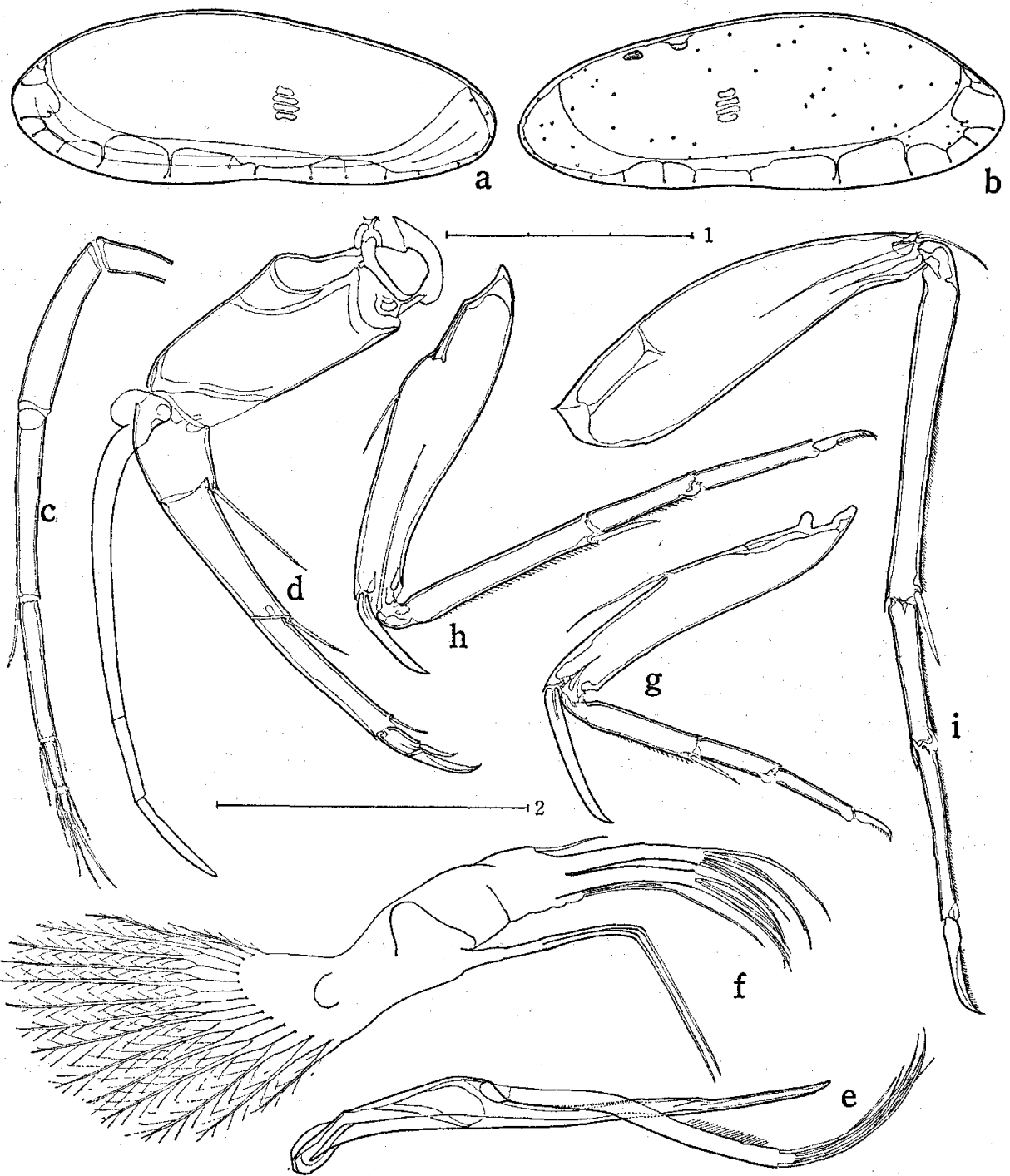

Fig. 14. Paradoxostoma depressum. a, b, $\approx(\mathrm{MO}-408) ; \mathrm{c-i}$, ㅇ (MO-409). a, left valve; b, right valve; $c$, antennula; $d$, antenna; e, mandible; $f$, maxillula; $g$, maxilla; $h$, thoracopoda 1 ; i, thoracopoda 2 .

Scale: $1(0.3 \mathrm{~mm})$ for $a, b ; 2(0.1 \mathrm{~mm})$ for $c-i$. 
Description. Left valve elongate reniform in lateral view; greatest height threeeighths of length, situated at anterior four-sevenths. Dorsal margin gently acrhed, without boundary angle postero-dorsally, with very faint angle antero-dorsally. Anterior margin rather evenly rounded; the extremity at lower third. Posterior margin narrowly rounded, the extremity at half length. Ventral margin almost straight, sinuated in front of the middle. Right valve sub-equal to the left in outline and structure, but a little shorter and higher; postero-dorsal margin slightly concave or almost straight.

Selvage not developed. Infold rather wide. Inner margin smooth. Two striae present. Fused zone absent along anterior margin, rather wide along the rest. Line of concrescence remarkably irregular, coinciding with inner margin at anteroand postero-ventral parts. Radial pore canals 18 in number; several anterior ones having no "inner ducts"; seventh and eighth ones from posterior end juxtaposed.

Antennula: distal five podomeres having length ratio of $7: 8: 6: 2: 1$. Antenna: distal four podomeres and (claw) showing length ratio of roughly $3: 4: 5: 1:(2)$; subterminal claw degenerated to be small seta; spinneret seta three-segmented in length ratio of 45:11:14; first segment with very faint signs of segmentation at distal twofifths.

Mandible: palp with six distal setae, no exopodite. Maxillula with palp.

Walking legs: second to fourth podomeres and claws of maxilla and thoracopoda $1 \& 2$ having length ratio of $(29: 22: 21: 14):(53: 28: 31: 17):(85: 38: 44: 27)$.

Copulatory organ: basal part lemon-shaped, with anterior projection; anterior process of curving rod with small appendage at the middle, middle process of wide obtuse triangular lamella with rounded anterior end and pointed posterior one; posterior process of slender thin lamella.

Material. MO-408, ðَ (holotype), LV(61-22), RV(60-22), K. MO-409, 우, LV(67-24), RV(66-25), K.

Occurrence. At Kojima Island, where it is not abundant.

Remarks. The new species resembles $P$. oshoroense Hiruta, 1975, and $P$. convexum and $P$. affine, but differs from them in the detailed shape and structure of valves and copulatory organs.

\section{Paradoxostoma fragile sp. nov.}

(Figs. $3 \mathrm{a}-\mathrm{c} ; 6 \mathrm{~d} ; 15 \mathrm{a}-\mathrm{i}$ )

Description. Garapace rather thin, covered with fine longitudinal striae coarsely. Left valve elongate reniform; greatest height at three-fifths of length from anterior end. Dorsal margin gently arched. Anterior margin evenly rounded. Posterior margin a little obliquely rounded, larger than the anterior; posterior extremity higher than the anterior. Ventral margin almost straight, slightly sinuated in front of the middle. Right valve sub-equal to the left; faint caudal process present.

Selvage moderately developed, peripheral. Infold somewhat narrow. Inner 
margin rather smooth. Fused zone medium in width, wider along antero-ventral, postero-ventral, posterior margins than the others. Line of concrescence irregular, coinciding with inner margin antero-ventrally. Radial pore canals about 18 in number; seventh and eighth ones from posterior end juxtaposed.

Antennula: length ratio of second to sixth podomeres 20:16:20:5:3. Antenna: length ratio of second to fifth podomeres $27: 29: 18+18: 6$; fifth podomere with strong anterior and thin posterior claws; spinneret seta three-segmented at ratio of $8: 2: 3$.

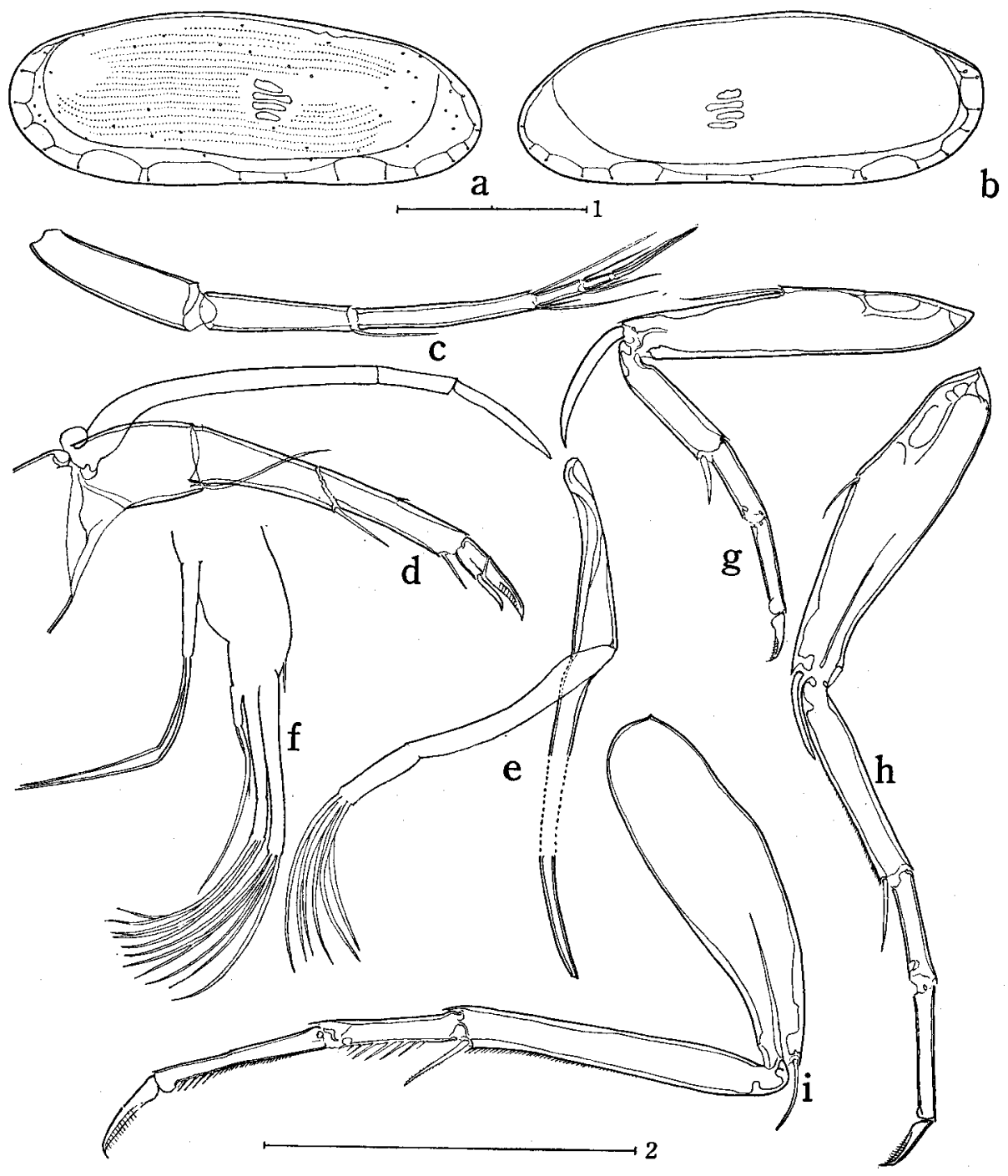

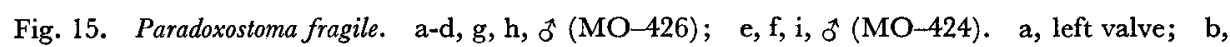
right valve; $c$, antennula; $\mathrm{d}$, antenna; $\mathrm{e}$, mandible; $\mathrm{f}$, maxillula; $\mathrm{g}$, maxilla; $\mathrm{h}$, thoracopoda $1 ; \mathrm{i}$, thoracopoda 2.

Scale: $1(0.2 \mathrm{~mm})$ for $a, b ; 2(0.1 \mathrm{~mm})$ for $c-i$. 
Mandible: palp without exopodite, provided with six setae distally. Maxillula with fine palp.

Walking legs: length ratio of second to fourth podomeres $(13: 9: 11):(22: 13: 15)$ : (35:16:19). Thoracopoda 1: protopodite with knee sub-claw. Thoracopoda 2: third podomere ornamented with several spinules along anterior margin, fourth podomere with a few, smaller spinules along the antero-distal.

Copulatory organ: basal part sub-square; anterior process distally widened lamella, middle process sub-triangular lamella with anterior verruca.

(Other characters: cf. generic description)

Material. MO-426, ơ (holotype), LV(51-19), RV(51-19), M. MO-427, 우, LV(50-20), RV(50-20), M. MO-424, ơ, LV(49-19), RV(48-?), M. MO-418, ?, LV(50-19), RV(50-19), M.

Occurrence. In about twenty stations I have examined, only at Maejima Island, where it is rather abundant then.

Remarks. This new species is rather small and fragile, and looks like an A-1 instar of a paradoxostome species. From its copulatory organs and its valves with fused zones developed well, however, it is thought to be an adult specimen. Thus, it is reported as a new species.

This species is characterized by its striated valves and its thoracopoda 2 with the third and fourth spinulated podomeres.

\section{Paradoxostoma lunatum sp. nov.}

(Figs. $3 \mathrm{~d}-\mathrm{h} ; 6 \mathrm{e} ; 16 \mathrm{a}-\mathrm{j}$ )

Description. Carapace remarkably compressed, of great sexual dimorphism in size, shape and coloration. Surface covered densely with very fine striae.

(Female) Black. Left valve lunate in lateral view. Dorsal margin evenly arched; greatest height slightly less than half length, just behind the middle. Anterior and posterior margins rounded; anterior extremity at lower fourth, the posterior at lower third. Ventral margin almost straight, slightly sinuated in the middle. Right valve sub-equal to the left in size and outline.

(Male) Black only at mid-dorsal area. Much smaller and lower than in female.

Selvage peripheral, moderately developed. Infold somewhat wide, anteriorly and postero-ventrally slightly wider. Inner margin smooth. Fused zone rather narrow in general, somewhat wider postero-ventrally, where it is half of infold in width. Line of concrescence rather smooth. Radial pore canals some twenty in number; sixth and seventh (or seventh and eighth) ones from posterior end juxtaposed at postero-ventral margin. Normal pore canals very small in number, scattered sparsely. Hingement very narrow.

Antennula: distal five podomeres having length ratio of 50:33:33:9:7. Antenna: length ratio of distal four podomeres 12:21:19:5; terminal claw one in number, subterminal claw degenerated to be very small seta; spinneret seta three-segmented at 
length ratio $15: 1: 2$.

Mandible: palp without exopodite, of three podomeres, distally with six setae. Maxillula: palp present.

Walking legs: second to fourth podomeres of walking legs having length ratio of $(6: 4: 5):(9: 5: 7):(12: 5: 9)$. Maxilla: knee claw strong, longer than second podomere; second podomere with very small seta. Thoracopoda 1: protopodite with knee sub-claw.

Copulatory organ: basal part sub-square, with two lamellar processes, anterior one leafy lamella with thumb-like core, middle one larger and tongue-shaped; spine slender.

(Other characters: $\mathrm{cf}$. generic description)
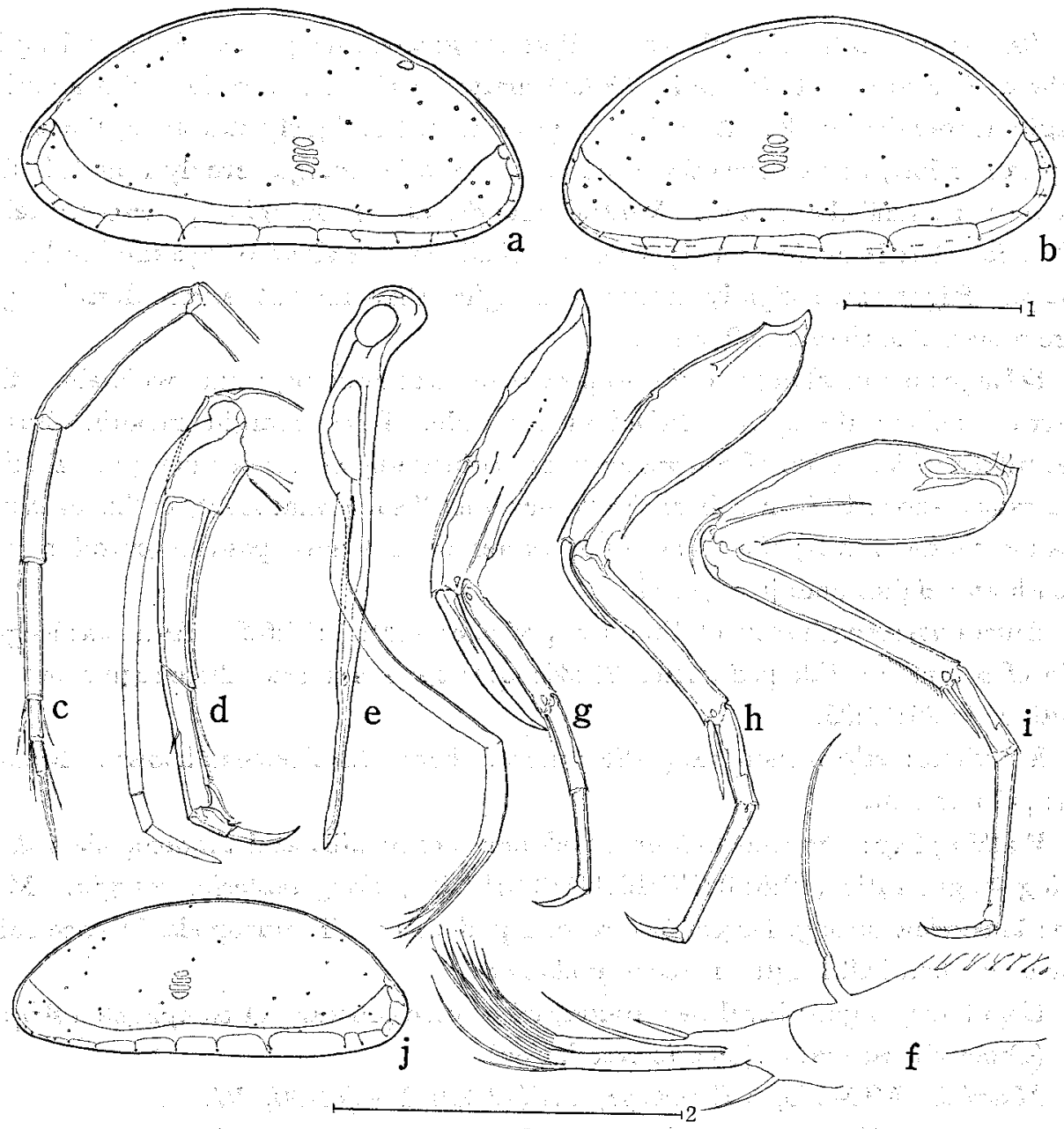

Fig. 16. Paradoxostoma lunatum. a-d, g-i, $q(\mathrm{MO}-491) ; \mathrm{e}$ \% (MO-447); f, $q$ (MO-382); j, $\widehat{o}(\mathrm{MO}-415)$ a, left valve; b, right valve; c, antennula; $d$, antenna; c, mandible; $f$, maxillula; $\mathrm{g}$, maxilla; $\mathrm{h}$, thoracopoda $1 ; \mathrm{i}$, thoracopoda 2 ; $\mathrm{j}$, right valve Scale: $1(0.2 \mathrm{~mm})$ for $\mathrm{a}, \mathrm{b}, \mathrm{j} ; 2(0.1 \mathrm{~mm})$ for $c-i$. 
Material. MO-491, 우 (holotype), LV(58-28), RV(58-28), MBS, 11-VI-1976. MO-382, q, LV(55-26), RV(54-26), MBS, 11-VII-1976. MO-447, ㅇ, LV(55-?), RV(54-25), A. MO-415, ðै, LV(47-19), RV(46-19), M.

Occurrence. Rare in the Inland Sea.

Remarks. This new species is similar to P. honssuensis (sic.) Schornikov, 1975, but differs from it in the detailed structure of valves and antennules; the penultimate podomere of the antennule is relatively short in this new species, very long in his.

\section{Paradoxostoma denticulatum sp. nov.}

(Figs. $3 \mathrm{i}-\mathrm{k} ; 5 \mathrm{~d} ; 17 \mathrm{a}-\mathrm{i}$ )

Description. Left valve elongate elliptical; greatest height two-fifths of length, at three-fifths from anterior end. Dorsal margin arched, connecting with anterior margin at rounded angle. Anterior margin rounded obliquely and small, the extremity rather low, at two-sevenths of height. Posterior margin evenly rounded, the extremity at half the height. Ventral margin almost straight, postero-ventrally with spine that is made of only calcified shell, independent of hyaline border or selvage. Right valve slightly shorter and higher than the left, antero-dorsal angle more remarkable than in left valve.

Selvage narrow along anterior to postero-ventral margins, rather wide along the posterior, behind the spine. Infold rather wide. Inner margin smooth. Fused zone rather wide. Line of concrescence not coinciding with inner margin. Radial pore canals about 18 in number; the "inner ducts" somewhat stout, unlike in usual paradoxostomid forms; sixth one from posterior end near postero-ventral spine, seventh and eighth ones juxtaposed.

Antennula: length ratio of distal five podomeres 20:17:17:6:2. Antenna: length ratio of second to fifth podomeres $23: 34: 38: 5$; spinneret seta three-segmented at length ratio $85: 17: 23$.

Mandible: palp without exopodite; the number of distal setae unknown. Maxillula: palp present.

Walking legs: Second to fourth podomeres of maxilla and thoracopoda 1 \& 2 having length ratio $(10: 8: 8):(16: 10: 11):(26: 12: 15)$, along posterior margin. Maxilla: knee claw strong, larger than second podomere. Thoracopoda 1: knee subclaw more than half length of second podomere.

Copulatory organ: basal part round, with three processes of complicated shape.

(Other characters: cf. generic description)

Material. MO-373, ơ (holotype), LV(72-29), RV(72-30), W.

Occurrence. Very rare. Only one specimen ( $\left.\delta^{\circ}\right)$ at Wasajima Island.

Remarks. This new species is characterized by the reniform valves with spines postero-ventrally. 

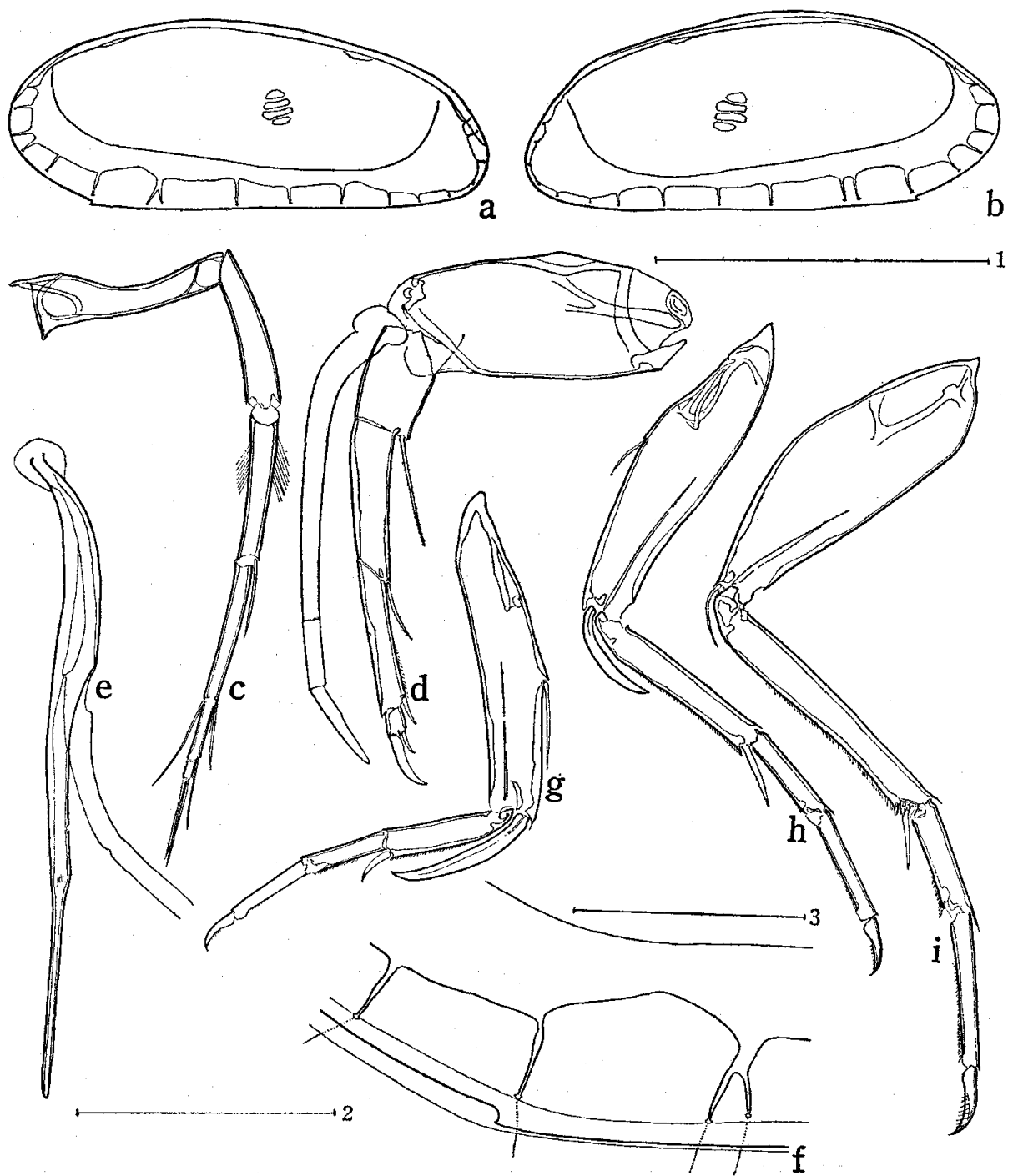

Fig. 17. Paradoxostoma denticulatum. ô (MO-373). a, left valve; b, right valve; c, antennula; $d$, antenna; e, mandible; $f$, postero-ventral margin of left valve; $g$, maxilla; $h$, thoracopoda 1 ; i, thoracopoda 2.

Scale: $1(0.5 \mathrm{~mm})$ for $\mathrm{a}, \mathrm{b} ; 2(0.1 \mathrm{~mm})$ for $\mathrm{c}-\mathrm{e}, \mathrm{g}-\mathrm{i} ; 3(0.1 \mathrm{~mm})$ for $\mathrm{f}$.

\section{Paradoxostoma rhomboideum sp. nov.}

(Figs. $31-n ; 5$ e; 18 a-i)

Description. Left valve of warped rhomboid; greatest height half of length, at three fifths of length from anterior end; both ends conspicuously different in height: anterior end at fourth, posterior end at three-fifths, of height. Dorsal margin evenly arched. Anterior margin narrowly rounded. Posterior margin with prominent high end, where caudal process exists; lower half long, very slightly concave. Ventral 
margin almost straight, slightly sinuated in front of middle. Right valve sub-equal to the left in size and shape; postero-dorsal margin slightly concave.

Selvage moderately developed. Infold rather wide. Inner margin smooth, subparallel to free margins. Fused zone somewhat wide along antero-ventral and posterior margins, narrow along the others. Line of concrescence somewhat irregular. Radial pore canals about twenty in number; no juxtaposed ones at postero-ventral margin..

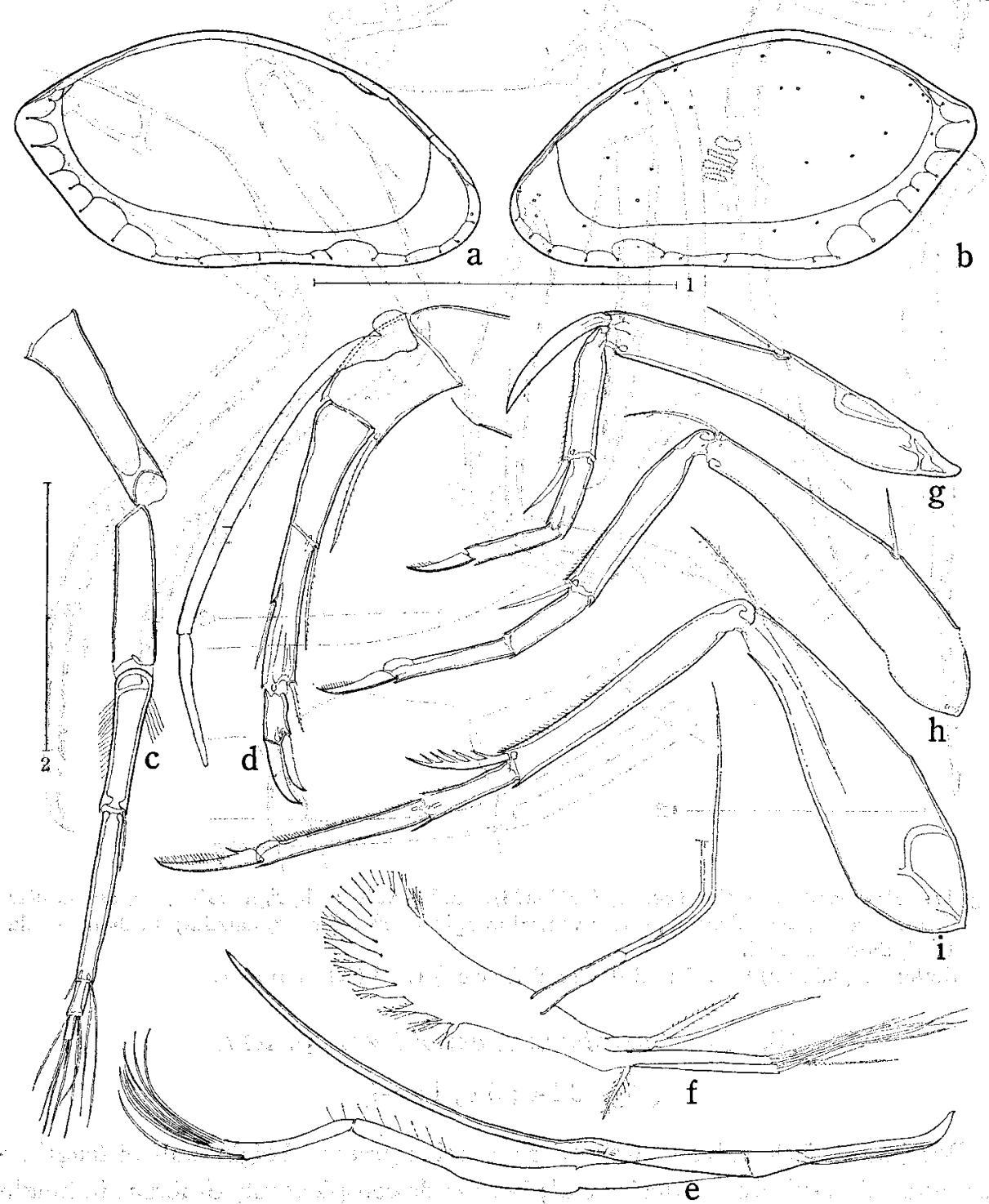

Fig. 18. Paradoxostoma rhomboideum. a-d, f-i, of (MO-412); e, 우 (MO-419). a, left valve; "b, right valve; $\quad c$, antennula; $d$, antenna; $e$, mandible (this mandible is about $4 / 5$ of that of MO-412 in length); $f$, maxillula; g, maxilla; $h$, thoracopoda 1 ; i, thoracopoda 2 . Scale: $1(0.5 \mathrm{~mm})$ for $a, b ; 2(0.1 \mathrm{~mm})$ for $\mathrm{c}-1$. 
Antennula: distal five podomeres having length ratio of $21: 18: 23: 4: 3$, third to fifth podomere heavily chitinized; fifth and sixth podomeres prominently short. Antenna: distal four podomeres showing length ratio of $16: 17: 11+11: 6$; spinneret seta three-segmented at ratio of $15: 6: 7$, first joint very faint.

Mandible: coxa very slender; lower part remarkably elongated, upper part scarsely widened; palp without exopodite, four-segmented, distally with seven setae. Maxillula: palp present.

Walking legs: distal three podomeres of maxilla and thoracopoda 1 \& 2 having length ratio $(29: 21: 23):(47: 25: 32):(69: 25: 47)$. Maxilla: endopodite relatively small. Thoracopoda 1: protopodite with distal seta, not claw. Thoracopoda 2: second podomere with several fine spinules round distal seta.

Copulatory organ: basal part semi-circular, with three flame-shaped processes bending backwards; anterior one narrow, with spine proximally; middle one largest, semi-lunate lamella; posterior one semi-lunate, with spine distally.

(Other characters : cf. generic description)

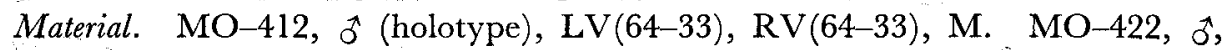
$\mathrm{LV}(61-30), \mathrm{RV}(61-31), \mathrm{M} . \mathrm{MO}-420$, + $, \mathrm{LV}(65-33), \mathrm{RV}(66-34), \mathrm{M} . \mathrm{MO}-421$, ㅇ, $\mathrm{LV}(65-33), \mathrm{RV}(65-34), \mathrm{M}$.

Occurrence. Only at the above locality and Aioi Gity, Hyogo Pref. (134 $28.4^{\prime} \mathrm{E}$, $\left.34^{\circ} 45.6^{\prime} \mathrm{N}\right)$, where it is abundant.

Remarks. This new species resembles $P$. aculeoliferum Schornikov, 1975, in the shape of valves, but differs from it in having no postero-ventral spine in the valve.

\section{Paradoxostoma setosum sp. nov.}

(Figs. $4 \mathrm{f}-\mathrm{h} ; 19 \mathrm{a}-\mathrm{h}$ )

Description. Left valve sub-elliptical; greatest height half of length, just behind the middle. Dorsal margin evenly arched. Anterior and posterior margins narrowly rounded; anterior extremity at three-tenths, the posterior at six-tenths, of height. Ventral margin almost straight along anterior half, ascending toward posterior end. Right valve similar to the left; caudal process more prominent.

Selvage well-developed. Infold rather wide. Inner margin smooth. Fused zone narrow. Line of concrescence smooth. Radial pore canals possessing "inner ducts" along antero-ventrally and posteriorly. Adductor muscle scars four in number, without additional scars.

Antennula : distal six podomeres having length ratio of 20:10:18:6:3. Antenna: distal four podomeres and claw having length ratio of $35: 28: 38: 10: 29$; subterminal claw altered to fine seta of half length of the claw; fourth podomere with posterodistal seta a little apart from the end; spinneret seta three-segmented in ratio of 24:7:17, distal segment unusually long.

Mandible: coxa conspicuously elongated; palp not studied. Maxillula: four long setae existing between branchial setae and vibratory juxtaposed setae.

Walking legs: length ratio of second to fourth podomeres of maxilla and thora- 
copoda 1 \& $2(32: 22: 20):(47: 27: 38):(61: 31: 43)$. Protopodites with complicated apodemes near knee. Thoracopoda 1: protopodite with seta antero-distally.

Copulatory organ: relatively large, a fifth of valve in size; basal part sub-square; anterior process leafy lamella, middle and posterior processes ensiform lamellar.

(Other characters: $c f$. generic description)

Material. MO-423, đ̛ (holotype), LV(51-25), RV(50-26), M.

Occurrence. Rare. Only one specimen in the above station.

Remarks. The new species resembles in general aspect $P$. pedale and its allied
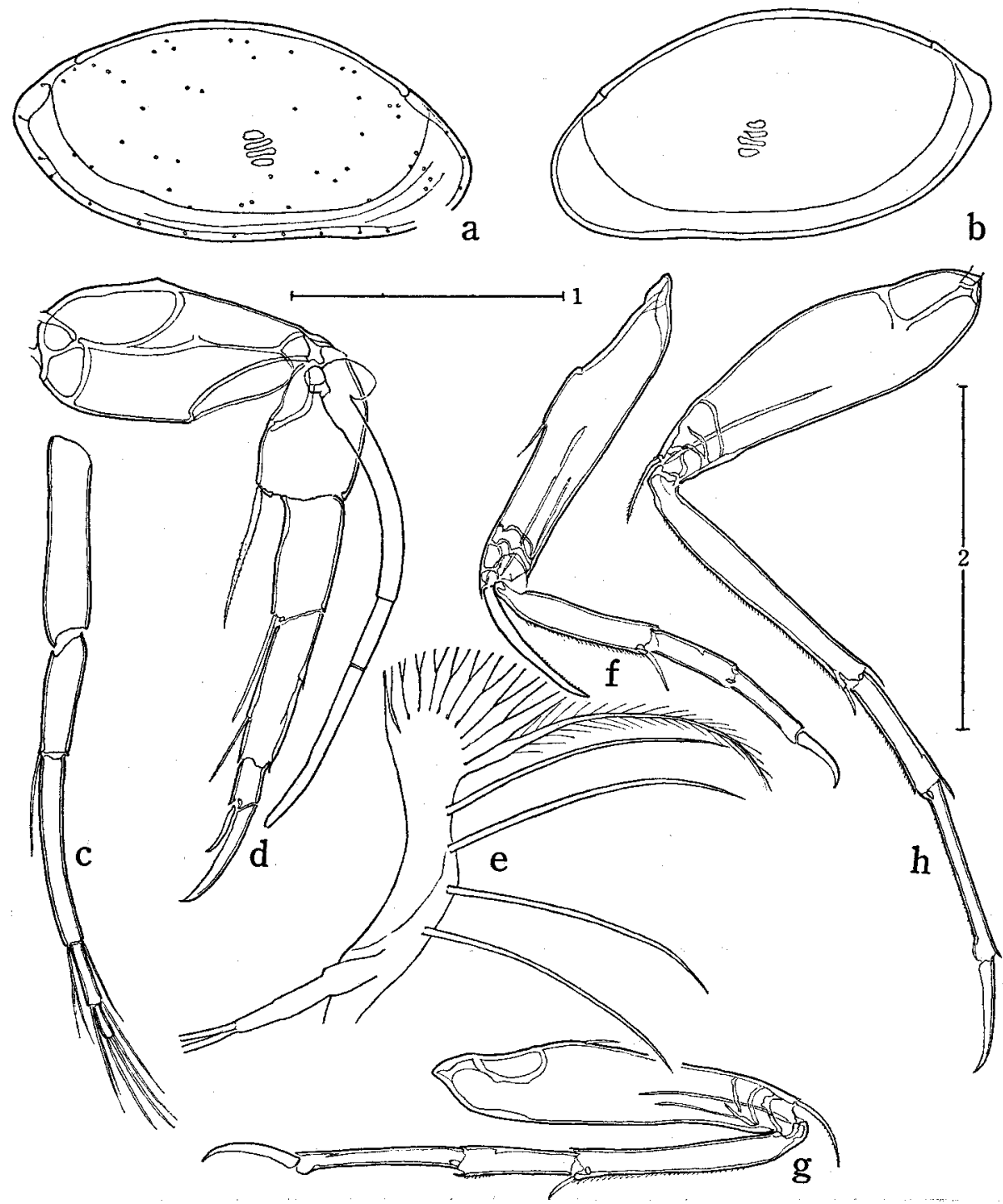

Fig. 19. Paradoxostoma setosum. ơ (MO-423). a, left valve; b, right valve;, c, antennula; d, antenna; e, maxillula; $f$, maxilla; $g$, thoracopoda 1 ; $h$, thoracopoda 2 . Scale: $1(0.3 \mathrm{~mm})$ for $a, b ; 2(0.1 \mathrm{~mm})$ for $c-h$. 
species, but differs widely from them in the following. 1) Antenna: terminal claw slender; spinneret seta with unusuall ylong distal segment. 2) Mandible: coxa remarkably elongated, as in $P$. rhomboideum. 3) Maxillula: four long setae existing between vibratory and branchial setae. 4) Walking legs: protopodites with apodemes distally.

\section{Affinity of Japanese Paradoxostome Species}

Hiruta (1975) has separated four species of Hokkaido into two groups with the shape of mandibles and maxillulae (maxillae in his). Both groups, however,

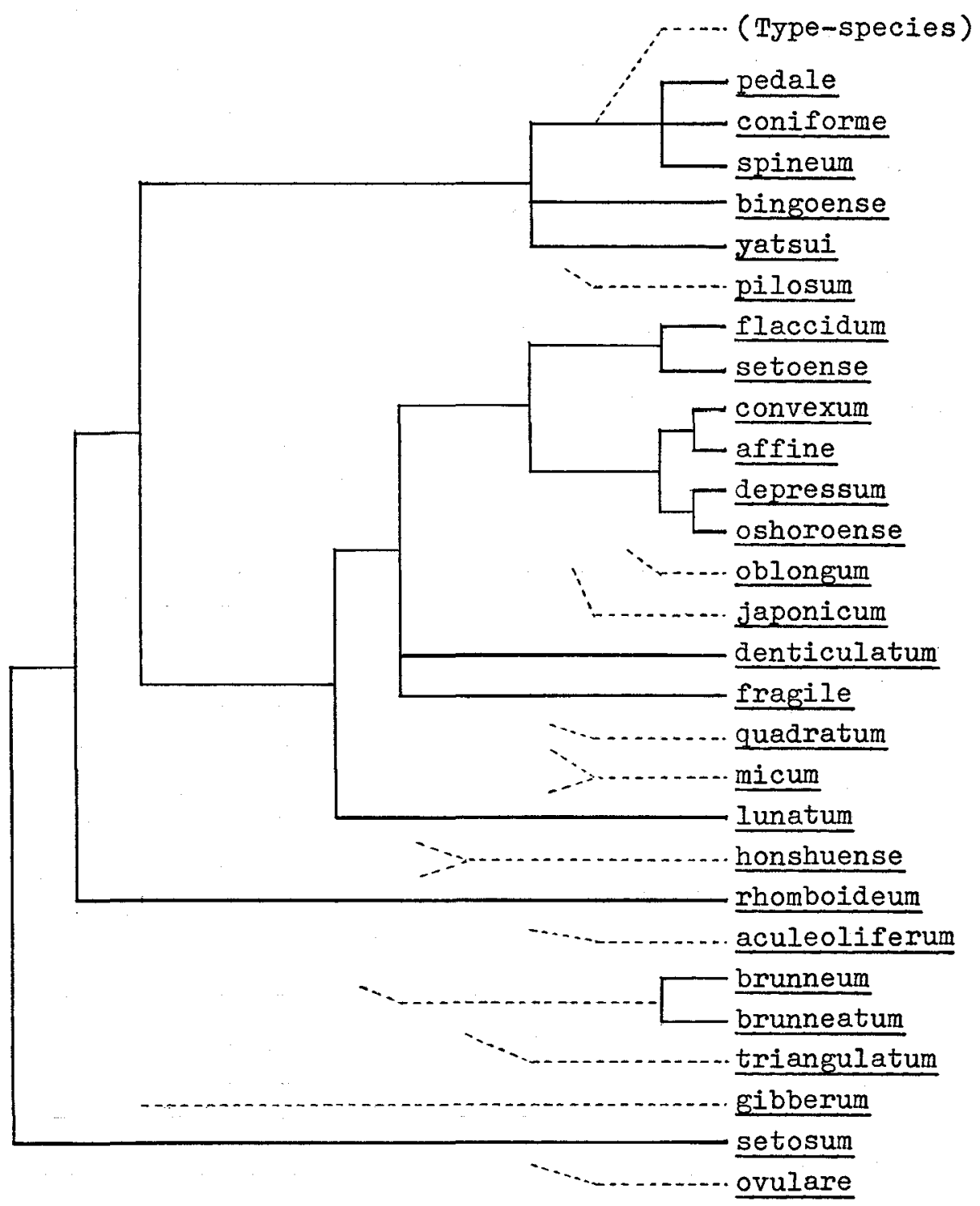

Fig. 20. An assumptive affinity of Japanese paradoxostome species. 
may be more easily distinguished with other characters. Then, all the Japanese paradoxostome species and the type-species that has not been reported from Japan are examined about the following respects; as shown in Table 1 .

1. Size - middle (more than $0.55 \mathrm{~mm}$ ) or small.

2. Shape - oval, reniform, lunate, quadrangular or triangular.

3. Selvage - wide, medium or narrow.

4. Fused Zone - wide, medium or narrow, as compared with infold.

Table 1. Distinguishing characters of Japanese paradoxostome species, except for copulatory organs.

\begin{tabular}{|c|c|c|c|c|c|c|c|c|c|c|c|c|c|}
\hline Species & $\mathrm{Si}$ & Sh & $\mathrm{Se}$ & FZ & FS & $\mathrm{OG}$ & $\mathrm{MC}$ & ME & $\mathrm{MP}$ & MX & $\mathrm{T} 1$ & \multicolumn{2}{|l|}{$\mathrm{T} 2$} \\
\hline (Type-species) & $\mathrm{m}$ & $\mathbf{o}$ & $w$ & $\mathrm{n}$ & $\mathbf{p}$ & & $\mathbf{n}$ & 一 & - & a & $\mathbf{s}$ & \multicolumn{2}{|l|}{ 一 } \\
\hline 1. pedale. & $\mathrm{m}$ & o & $w$ & $\mathrm{n}$ & $\mathrm{p}$ & & $\mathbf{n}$ & $\mathbf{p}$ & 7 & a & $\mathbf{s}$ & \multicolumn{2}{|l|}{2,4} \\
\hline 2. coniforme & $\mathrm{m}$ & o & $w$ & n & $\mathrm{p}$ & & $\mathrm{n}$ & $\mathrm{p}$ & 7 & a & s & \multicolumn{2}{|l|}{2,4} \\
\hline spineum $(\mathrm{H})$ & $\mathrm{m}$ & 0 & $w$ & $\mathrm{n}$ & $\mathrm{p}$ & & $\mathbf{n}$ & $\mathbf{p}$ & 7 & a & $\mathrm{s}$ & \multicolumn{2}{|l|}{2,4} \\
\hline 3. bingoense & $\mathrm{m}$ & o & w & $\mathbf{n}$ & $\mathrm{p}$ & & $\mathbf{n}$ & $\mathrm{p}$ & 7 & a & $\mathrm{s}$ & \multicolumn{2}{|l|}{2} \\
\hline 4. yatsui & $\mathrm{m}$ & o & w & $\mathrm{n}$ & $\mathrm{p}$ & $\mathrm{p}$ & $\mathrm{n}$ & $\mathrm{p}$ & 7 & $\mathbf{a}$ & s & \multicolumn{2}{|l|}{2} \\
\hline pilosum $(\mathbf{K})$ & s? & o & - & - & - & $\mathrm{p} ?$ & - & - & - & - & - & \multicolumn{2}{|l|}{-} \\
\hline 5. flaccidum & $\mathrm{m}$ & $\mathbf{r}$ & $\mathrm{nm}$ & $\mathrm{m}$ & $\mathbf{a}$ & & $\mathrm{n}$ & $\mathbf{a}$ & 6 & $\mathrm{p}$ & c & \multicolumn{2}{|l|}{3} \\
\hline 6. setoense & $\mathbf{m}$ & $\mathbf{r}$ & $\mathbf{n m}$ & $\mathrm{m}$ & a & & $\mathrm{n}$ & a & 6 & $\mathrm{p}$ & c & \multicolumn{2}{|l|}{3} \\
\hline 7. convexum & $\mathrm{m}$ & $\mathbf{r}$ & $\mathbf{n}$ & $\mathrm{m}$ & a & & $\mathrm{n}$ & a & 6 & $\mathrm{p}$ & c & \multicolumn{2}{|l|}{ a } \\
\hline 8. affine & $\mathrm{m}$ & $\mathbf{r}$ & $\mathrm{n}$ & $\mathrm{m}$ & $\mathrm{a}$ & & $\mathrm{n}$ & $\mathbf{a}$ & 6 & $\mathrm{p}$ & $\mathrm{c}$ & \multicolumn{2}{|l|}{$a$} \\
\hline 9. depressum & $\mathrm{m}$ & $\mathbf{r}$ & $\mathrm{n}$ & $\mathrm{m}$ & a & 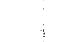 & $\mathbf{n}$ & $\mathbf{a}$ & 6 & $\mathrm{p}$ & c & \multicolumn{2}{|l|}{ a } \\
\hline oshoroense $(\mathrm{H})$ & m & $\mathbf{r}$ & $\mathbf{n}$ & $\mathbf{m}$ & $\mathbf{a}$ & $\vdots$ & $\mathbf{n}$ & $\mathbf{a}$ & 6 & $\mathrm{p}$ & $\mathrm{c}$ & \multicolumn{2}{|l|}{$a$} \\
\hline oblongum $(\mathbf{K})$ & $\mathbf{m}$ & $\mathbf{r}$ & - & - & - & & $一$ & - & - & - & - & \multicolumn{2}{|l|}{ - } \\
\hline japonicum (S) & s & $\mathbf{r}$ & $\because$ & $w$ & - & & $\mathbf{n}$ & $\mathrm{a}$ & - & - & - & \multicolumn{2}{|l|}{ 一 } \\
\hline 12. denticulatum & $\mathrm{m}$ & $\mathbf{r}$ & $\mathrm{mw}$ & $\mathrm{m}$ & $\mathbf{a}$ & $\mathrm{d}, \dot{\mathrm{r}}$ & $\mathbf{n}$ & $\mathbf{a}$ & 一 & $\mathrm{p}$ & c & \multicolumn{2}{|l|}{$a$} \\
\hline 10. fragile & $\mathrm{s}$ & $\mathrm{r}$ & $\mathrm{m}$ & $\mathrm{m}$ & $\mathbf{a}$ & $\mathbf{s}$ & $\mathrm{n}$ & a. & 6 & $p$ & $\mathbf{c}$ & \multicolumn{2}{|l|}{3,4} \\
\hline quadratum $(\mathbf{K})$ & $\mathrm{s}$ & $\mathrm{r}$ & - & - & - & & - & 一 & 一 & 一 & - & \multicolumn{2}{|l|}{ - } \\
\hline micum $(\mathbf{S})$ & $-s$ & $\mathbf{r}$ & - & $\mathrm{m}$ & $\mathrm{p} ?$ & & $\mathbf{n}$ & $\mathrm{a}$ & 4 & $\mathrm{p}$ & 一 & \multicolumn{2}{|l|}{ - } \\
\hline \multirow{2}{*}{$\begin{array}{l}\text { 11. lunatum } \\
\text { honshuense }(\mathrm{S})\end{array}$} & $\mathrm{s}$ & 1 & m & $\mathrm{m}$ & $\mathbf{a}$ & s & $\mathrm{n}$ & $\mathbf{a}$ & 6 & $\mathrm{p}$ & c & \multicolumn{2}{|l|}{$a$} \\
\hline & $\mathrm{m}$ & 1 & - & $\mathrm{m}$ & $a ?$ & $s$ & $\mathrm{e}$ & 一 & 7 & a & $?$ & \multicolumn{2}{|l|}{$a$} \\
\hline 13. rhomboideum & $\mathrm{m}$ & $q$ & $\mathrm{~m}$ & $\mathbf{m}$ & $\mathbf{a}$ & & e & $\mathbf{a}$ & 7 & $\mathrm{p}$ & s & \multirow{2}{*}{\multicolumn{2}{|c|}{ s }} \\
\hline aculeoliferum $(\mathbf{S})$ & $\mathrm{m}$ & $q$ & - & $\mathrm{m}$. & $p$ ? & $\mathrm{d}$ & $\mathbf{n}$ & $\mathrm{p}$ & $\therefore$ & a & $\ldots \mathbf{s}$ & & \\
\hline brunneum (S) & $\mathrm{s}$ & $q$ & - & $\mathbf{w}$ & $\mathbf{a}$ & & e & $\mathrm{p}$ & 7 & $\mathbf{a}$ & $\mathbf{s}$ & \multicolumn{2}{|c|}{ a } \\
\hline brunneatum (S) & s & $q$ & - & w & $\mathrm{a}$ & & $\mathrm{e}$ & $\mathrm{p}$ & 7 & $\mathrm{a}$ & - & \multicolumn{2}{|c|}{ - : } \\
\hline triangulatum $(\mathrm{K})$ & s & $q$ & - & $\mathrm{m}$ & - & & 一 & 一 & 一 & - & - & \multicolumn{2}{|c|}{-} \\
\hline gibberum $(\mathrm{S})$ & s & $\mathrm{t}$ & - & $\mathrm{m}$ & a & & $\mathrm{n}$ & $\mathrm{p}$ & 7 & a & $\mathbf{s}$ & $\mathrm{a}$ & \\
\hline 14. setosum & s & o & $w$ & $\mathbf{n}$ & $\mathbf{a}$ & & $\mathbf{e}$ & - & - & - & $\mathbf{s}$ & a & \\
\hline ovulare $(\mathbf{K})$ & s & o & - & - & 一 & & - & - & - & - & - & - & \\
\hline
\end{tabular}

* Capitals in parentheses show authors describing the species. H: Hiruta, K: Kajiyama, S: Schornikov.

* Characters of type-species are based on Sars's (1928) 
5. Two Frontal Scars of adductor muscle scars - present or absent.

6. Other Characters of valves - striated; denticulated; with prominent caudal process; with thick radial pore canals.

7. Mandibular Coxa - normal (as paradoxostome species) or elongated.

8. Mandibular Exopodite - present or absent.

9. Mandibular Palp - with 4, 6 or 7 setae.

10. MaXillulary Palp - present or absent.

11. Thoracopoda $\mathbf{1}$ - with knee claw or seta.

12. Thoracopoda $\mathbf{2}$ - spinules existing on 2nd (distally), 3rd (anteriorly) and/or 4th (anteriorly) podomeres, or on seta of 2nd podomere, or absent.

(In the table 1, the above gothic marks are used.)

Table 1 reveals that some common characters occur in closely related species. For example, the oval species with the wide selvage, the narrow fused zone and two frontal scars, possesses the mandible with a exopodite and seven setae, the maxillula without a palp and the thoracopoda 1 with a knee seta. The reniform valve, the narrow or medium selvage, the medium fused zone, no frontal scars, the mandible with six setae and no exopodite and the thoracopoda 1 with a knee claw also occur in other species in common.

From the table 1, some classifications are supposed. With due regard to also the shape of copulatory organs, an affinity of these species is postulated in Fig. 20. Deficient information may make it incomplete or even erroneous in part. None the less, this assumptive figure may become the beginning for the more exact taxonomy of the species belonging to the genus Paradoxostoma.

\section{LITERATURE}

Hanai, 'T., 1959. Studies on the Ostracoda from Japan. J. Fac. Sci. Univ. Tokyo, (II), 11 ; 419-439.

- 1965. Ostracoda. In: OKADA et al., New Illustrated Encyclopedia of the Fauna of Japan, II : 456.

Hiruta, S., 1975. Studies on the Recent Marine Ostracoda from Hokkaido, I. J. Fac. Sci. Hokkaido Univ., (VI), 20: 117-140, pl. 4.

Ishizaki, K., 1968. Ostracodes from Uranouchi Bay, Kochi Prefecture, Japan. Sci. Rept. Tohoku Univ., (II), 40: 1-45, pls. 1-9.

- 1969. Ostracodes from Shinjiko and Nakanoumi, Shimane Prefecture, Western Honshu, Japan. Ibid., 41 : 197-224, pls. 24-26.

——1971. Ostracodes from Aomori Bay, Aomori Prefecture, Northeast Honshu, Japan. Ibid., 43: 59-97. pls. $1-7$.

- 1976 . The basin development of the Diluvium Furuya Mud Basin, Shizuoka Prefecture, Japan, based on faunal analysis of fossil ostracodes. Progress in Micropaleontology, 118-143, pls. $1-4$.

Kajiyama, E., 1913. The ostracodes from Misaki, pt. 3. Zool. Mag., Tokyo, 25: 1-16, 1 pl. (In Japanese)

Müller, G.W., 1894. Die Ostracoden des Golfes von Neapel und der angrenzenden Meeres-Abschnitte. Fauna Flora Golf. Neapel Monogr., 21, viii 404 pp, 40 pls.

Sars, G.O., 1928. Ostracoda. An account of the Crustacea of Norway. Vol. 9, xii +277 pp., 119 pls.

Schornikov, E.I., 1975. Ostracod fauna of the intertidal zone in the vicinity of the Seto Marine Biological Laboratory. Publ. Seto Mar. Biol. Lab., 22: 1-30. 